\title{
Capital Flows and Financial Stability: Monetary Policy and Macroprudential Responses*
}

\author{
D. Filiz Unsal \\ International Monetary Fund
}

\begin{abstract}
The resumption of capital flows to emerging-market economies since mid-2009 has posed two sets of interrelated challenges for policymakers: (i) to prevent capital flows from exacerbating overheating pressures and consequent inflation, and (ii) to minimize the risk that prolonged periods of easy financing conditions will undermine financial stability. While conventional monetary policy maintains its role in counteracting the former, there are doubts that it is sufficient to guard against the risks of financial instability. In this context, there have been increased calls for the development of macroprudential measures globally. Against this background, this paper analyzes the interplay between monetary and macroprudential policies in an open-economy DSGE model. The key result is that macroprudential measures can usefully complement monetary policy under a financial shock that triggers capital inflows. Even under the "optimal simple rules," introducing macroprudential measures improves welfare. Broad macroprudential measures are shown to be more effective than those that
\end{abstract}

*I am grateful to the editor Douglas Gale and an anonymous referee for valuable comments and suggestions. I also thank the participants at the IJCB 4th Financial Stability Conference on "Financial Crises: Causes, Consequences, and Policy Options," particularly Gianluca Benigno, Gianni De Nicolo, and Rafael Portillo. Roberto Cardarelli, Sonali Jain-Chandra, Nicolás Eyzaguirre, Jinill Kim, Nobuhiro Kiyotaki, Jaewoo Lee, and Steve Phillips; seminar participants in the IMF, in Korea University, and in the Central Bank of Turkey; and participants at the KIEP-IMF Joint Conference also provided insightful comments and suggestions. The usual disclaimer applies. Author contact: Research Department, International Monetary Fund, 700 19th Street, N.W., Washington, DC 20431, USA; Tel: 202-623-0784; E-mail:dunsal@imf.org. 
discriminate against foreign liabilities (macroprudential capital controls). We also show that the exchange rate regime matters for the desirability of a macroprudential instrument as a separate policy tool. Nevertheless, macroprudential measures may not be as useful in helping economic stability under different shocks. Therefore, shock-specific flexibility in the implementation is desirable.

JEL Codes: E52, E61, F41.

\section{Introduction}

Unusually strong cyclical and policy differences between advanced and emerging economies, and a gradual shift in portfolio allocation towards emerging markets, have led to capital flows into emergingmarket economies since mid-2009. This rapid resumption of capital inflows, which are large in historical context, has posed risks to macroeconomic and financial stability. To address these risks, policymakers have turned their attention to the use of macroprudential measures, in addition to monetary policy.

Past experience has shown that macroeconomic stability is not a sufficient condition for financial stability. For example, prior to the crisis, financial imbalances built up in advanced economies despite stable growth and low inflation. Moreover, microprudential regulation and supervision, which focus on ensuring safety and soundness of individual financial institutions, turned out to be inadequate, as systemwide risks could not be contained. Hence, a different approach based on macroprudential supervision has started to be implemented in several emerging-market economies.

Macroprudential measures are defined as regulatory policies that aim to reduce systemic risks, ensure stability of the financial system as a whole against domestic and external shocks, and ensure that it continues to function effectively (Bank for International Settlements 2010). During boom times, perceived risk declines, asset prices increase, and lending and leverage become mutually reinforcing. The opposite happens during a bust phase: a vicious cycle can arise between deleveraging, asset sales, and the real economy. This amplifying role of financial systems in propagating shocks - the so-called financial accelerator mechanism - implies procyclicality of financial conditions. In principle, macroprudential measures could 
address procyclicality of financial markets by making it harder to borrow during the boom times, and therefore make the subsequent reversal less dramatic, thus reducing the amplitude of the boom-bust cycles by design.

Both changes in policy interest rates and macroprudential measures affect aggregate demand and supply as well as financial conditions in similar ways. On the one hand, monetary policy affects asset prices and financial markets in general. Indeed, asset prices are one channel through which monetary policy operates. On the other hand, macroprudential policies have macroeconomic spillovers, through cushioning or amplifying the economic cycle, or, for example, by directly affecting the provision of credit.

Nevertheless, the two instruments are not perfect substitutes and can usefully complement each other, especially in the presence of large capital inflows that tend to increase vulnerabilities of the financial system. First, the policy rate may be "too blunt" an instrument, as it impacts all lending activities regardless of whether they represent a risk to stability of the economy. ${ }^{1}$ The interest rate increase required to deleverage specific sectors might be so large as to bring unduly large aggregate economic volatility. By contrast, macroprudential regulations can be aimed specifically at markets in which the risk of financial stability is believed to be excessive. ${ }^{2}$ Second, in economies with open financial accounts, an increase in the interest rate might have only a limited impact on credit expansion if firms can borrow at a lower rate abroad. Moreover, although monetary transmission works well through the asset-price channel in "normal" times, in "abnormal" times sizable rapid changes in risk premiums could offset or diminish the impact of policy rate changes on credit growth and asset prices (Kohn 2008; Bank of England 2009). Third, and perhaps more importantly, interest rate movements aiming to ensure financial stability could be inconsistent with those required to achieve macroeconomic stability, and that discrepancy could risk de-anchoring inflation expectations (Borio and Lowe 2002; Mishkin

\footnotetext{
${ }^{1}$ See, among many others, Ostry et al. (2010).

${ }^{2}$ The bluntness of the policy rate could also be its advantage over macroprudential measures, as it is difficult to circumvent a rise in borrowing costs brought by policy rates in the same way as regulations can be avoided. See Bank for International Settlements (2010) and Ingves (2011).
} 
2007). For example, under an inflation-targeting framework, if the inflation outlook is consistent with the target, a response to assetprice fluctuations to maintain financial stability may damage the credibility of the policy framework.

One initial question, however, is how a policy intervention to private borrowing decisions is justified in economic terms. This question can be answered in two main ways: first, by reference to negative externalities that arise because agents do not internalize the effect of their individual decisions, which are distorted towards excessive borrowing, on financial instability; and, second, by reference to the potential role of macroprudential regulations in mitigating the standard Keynesian impact of shocks - a decrease in aggregate demand and output, associated with a lower inflation - that cannot be fully offset by monetary and/or fiscal policies alone. There is a rapidly growing literature on both fronts. On the first, Korinek (2009), Bianchi and Mendoza (2010), Jeanne and Korinek (2010), and Bianchi (2011) focus on "overborrowing" and consequent externalities. In these papers, regulations induce agents to internalize the externalities associated with their decisions and thereby increase macroeconomic stability. "Overborrowing," however, is a model-specific feature. For example, Benigno et al. (2012) find that in normal times, "underborrowing" is much more likely to emerge than "overborrowing."

This paper fits into the latter strand of research. Only recently have several studies started analyzing interactions between monetary policy and macroprudential measures. Angeloni and Faia (2009), Kannan, Rabanal, and Scott (2009), N'Diaye (2009), and Angeloni, Faia, and Lo Duca (2010) incorporate macroprudential instruments into general equilibrium models where monetary policy has a non-trivial role in stabilizing the economy after a shock. However, all of these papers either feature a closed economy or do not explicitly model the financial sector.

We analyze the trade-offs and complementarities between monetary and macroprudential policy rules (in the latter case, a rule that responds to credit growth) in mitigating the impact of two shocks that trigger capital inflows to the domestic economy: (i) a financial shock (a shock to investors' perception) and (ii) a shock to productivity. This paper complements the existing literature in two ways. First, we add an open-economy dimension with a fully articulated financial sector from the first principles. The model allows 
a quantitative assessment of alternative monetary and macroprudential responses to capital inflow surges. The open-economy feature of the model also enables us to consider the incidence of the exchange rate regime on the relevance of macroprudential measures. Further, we can assess the stabilization performance of macroprudential measures that discriminate against foreign liabilitiesmacroprudential capital controls - versus broad macroprudential measures, as entrepreneurs borrow from both domestic and foreign resources in the model. Second, the paper presents a welfare evaluation of alternative monetary and macroprudential policies. The literature has so far focused on ad hoc specifications of a welfare measure, which could result in biased policy evaluations. We numerically compute welfare and derive welfare-maximizing policy options based on a second-order approximation of households' utility function.

Our model features the financial accelerator mechanism developed by Bernanke, Gertler, and Gilchrist (1999) and draws on elements of models by Gertler, Gilchrist, and Natalucci (2007), Kannan, Rabanal, and Scott (2009), and particularly Ozkan and Unsal (2010). The corporate sector plays a key role in the modelthey decide the production and investment of capital, which is an asset and a way of accumulating wealth. In order to finance their investments, corporations partially use internal funds. However, they also use external financing which is more costly, with the difference termed "the default premium," linking the terms of credit and balance sheet conditions. Macroprudential policy rule (that responds to nominal credit growth) entails higher costs for financial intermediaries that are passed on to borrowers in the form of higher lending rates. Therefore, in the model, macroprudential measures are defined as an additional "regulation premium" that adds to entrepreneurs' cost of borrowing. ${ }^{3}$ This setup captures the notion that such measures make it harder for firms to borrow during boom times and hence make the subsequent bust less dramatic.

In our framework, investors' perception of risk declines under the (positive) financial shock, which provides easier credit conditions and hence triggers capital inflows. As financing costs decline, firms borrow and invest more. Stronger demand for goods and higher asset

\footnotetext{
${ }^{3}$ In the case of macroprudential capital controls, the regulation premium only applies to foreign borrowing.
} 
prices boost firms' balance sheet and reduce the default premium further. Eventually, higher leverage brings a higher default premium, capital inflows slow, and financial conditions normalize. However, both monetary and macroprudential policies have a non-trivial role in mitigating the impact of the shock.

We show that macroprudential policies help monetary policy stabilize the economy in the face of the financial shock. This is because they can offset the impact of the shock on entrepreneurs' borrowing costs without distorting consumption decisions by households. We find that even under the "optimal simple rules," introducing macroprudential measures is welfare improving. However, broad macroprudential measures are more effective than macroprudential capital controls, as the latter only bring a shift from foreign debt to domestic debt and hence affect the composition of entrepreneurs' debt, rather than the total volume.

Our results also yield that the exchange rate regime matters for the desirability of using a macroprudential instrument as a separate policy tool. Ceteris paribus, financial shocks have larger effects on inflation and output under the fixed exchange rate regime compared with the flexible exchange rate regime where the nominal exchange rate appreciation helps to limit the overheating and inflation pressures. In the absence of an independent policy tool under the pegged exchange rate (and free capital mobility), macroprudential policies become the only tool available to deal with aggregate demand stabilization.

Nevertheless, macroprudential measures may not be as useful in helping economic stability under different shocks. Under a positive productivity shock, for example, credit increases while inflation decreases. Macroprudential policies that respond to credit growth choke the desired expansion in credit brought by the endogenous monetary policy easing. Hence, there is a trade-off between financial and macroeconomic stability objectives in the face of a productivity shock, and macroprudential measures are not welfare improving. This implies that shock-specific flexibility in the implementation of macroprudential policies is desirable.

The remainder of the paper is organized as follows. Section 2 sets out the structure of the model by describing household, firm, and entrepreneurial behavior with a special emphasis on financial intermediaries and macroprudential policies. Section 3 describes the 
calibration, solution, and evaluation of the model. Section 4 presents impulse responses to a financial shock under alternative monetary and macroprudential policies. Section 5 provides a welfare analysis of alternative policy responses. Section 6 discusses macroeconomic dynamics and a welfare evaluation under a productivity shock. Finally, section 7 provides the concluding remarks.

\section{The Model}

The world economy consists of two economies: a domestic economy and a foreign economy (rest of the world), each of which is inhabited by infinitely lived households. The total measure of the world economy is normalized to unity, with domestic and foreign having measure $n$ and $(1-n)$, respectively. Following Galí and Monacelli (2005), Faia and Monacelli (2007), and De Paoli (2009), among many others, we assume that the domestic economy is very small in size relative to the rest of the world to characterize an emerging, open-economy case. $^{4}$

Three important modifications are introduced in this paper. First, we incorporate macroprudential measures into the monetary policy framework in a relatively traceable manner. Second, we allow entrepreneurs to borrow both from domestic and foreign resources. As will be explained later, this is a crucial departure in order to differentiate macroprudential measures that discriminate against foreign liabilities (macroprudential capital controls) from more broad macroprudential measures. Third, capital inflows to the domestic, open economy are modeled as a favorable change in the perception of lenders. As they become "overoptimistic" about the domestic economy, financing conditions become easier. This is an intuitive and likely realistic representation of what is going on in financial markets during sudden swings of capital across countries.

There are three types of firms in the model. Production firms produce a differentiated final consumption good using both capital

\footnotetext{
${ }^{4}$ Despite the fact that the domestic economy is very small in size relative to the rest of the world, we choose to use a two-country model for greater realism, as it allows for some (small) feedback effects, which are general equilibrium in nature. However, simulations for the specification where the size of the domestic economy is infinitely small yield qualitatively similar results.
} 
and labor as inputs. These firms engage in local currency pricing and face price adjustment costs. As a result, final goods' prices are sticky in terms of the local exchange rate of the country in which they are sold. Importing firms that sell the goods produced in the foreign economy also have some market power and face adjustment costs in changing prices. Price stickiness in export and import prices causes the law of one price to fail such that exchange rate pass-through is incomplete in the short run. Finally, there are competitive firms that combine investment with rented capital to produce unfinished capital goods that are then sold to entrepreneurs.

Entrepreneurs play a major role in the model. They produce capital, which is rented to firms, and finance their investment in capital through internal funds as well as external borrowing; however, agency costs make the latter more expensive than the former. As monitoring the business activity of borrowers is a costly activity, lenders must be compensated by an external finance premium in addition to the foreign or domestic interest rate. The magnitude of this premium varies with the leverage of the entrepreneurs, linking the terms of credit to balance sheet conditions.

In our framework, macroprudential measures entail an increase in financial intermediaries' lending costs, which are then passed on to borrowers in the form of higher interest rates. We refer to the increased lending rates brought by macroprudential measures as the "regulation premium" and maintain that it is positively linked to nominal credit growth. Macroprudential policy is therefore countercyclical by design: countervailing to the natural decline in perceived risk in good times and the subsequent rise in the perceived risk in bad times.

The model for the domestic economy is presented in this section, and we use a similar version of the model for the rest of the world. ${ }^{5}$ Although asymmetric in size, the domestic economy and the rest of the world share the same preferences, technology, and market structure for consumption and capital goods. In what follows, variables without superscripts refer to the domestic economy, while variables with a star indicate the rest-of-the-world variables unless indicated otherwise.

\footnotetext{
${ }^{5}$ Appendices 1 and 2 present the model equations for the domestic small open economy and the rest of the world, respectively.
} 


\subsection{Households}

A representative household is infinitely lived and seeks to maximize

$$
E_{0} \sum_{t=0}^{\infty} \beta^{t} \frac{1}{1-\sigma}\left(C_{t}-\frac{\chi}{1+\varphi} H_{t}^{1+\varphi}\right)^{1-\sigma}
$$

where $C_{t}$ is a composite consumption index, $H_{t}$ is hours of work, $E_{t}$ is the mathematical expectation conditional upon information available at $t, 0<\beta<1$ is the representative consumer's subjective discount factor, $\sigma>0$ is the inverse of the intertemporal elasticity of substitution, $\chi>0$ is the utility weight of labor, and $\varphi>0$ is the inverse elasticity of labor supply. Our specification for households' utility allows for Greenwood, Hercowitz, and Huffman (1988) (GHH hereafter) preferences over hours, which eliminates wealth effects from labor supply. ${ }^{6}$

The composite consumption index, $C_{t}$, is given by

$$
C_{t}=\left[(1-\alpha)^{\frac{1}{\gamma}} C_{H, t}^{(\gamma-1) / \gamma}+(\alpha)^{\frac{1}{\gamma}} C_{M, t}^{(\gamma-1) / \gamma}\right]^{\gamma /(\gamma-1)},
$$

where $\gamma>0$ is the elasticity of substitution between domestic and imported (foreign) goods, and $0<\alpha<1$ denotes the weight of imported goods in the domestic consumption basket. This weight, $\alpha \equiv(1-n) v$, depends on $(1-n)$, the relative size of the foreign economy, and on $v$, the degree of trade openness of the domestic economy. $C_{H, t}$ and $C_{M, t}$ are constant elasticity of substitution indices of consumption of domestic and foreign goods, represented by

$$
\begin{aligned}
C_{H, t} & =\left[\int_{0}^{1} C_{H, t}(j)^{(\lambda-1) / \lambda} d j\right]^{\lambda /(\lambda-1)}, \\
C_{M, t} & =\left[\int_{0}^{1} C_{M, t}(j)^{(\lambda-1) / \lambda} d j\right]^{\lambda /(\lambda-1)},
\end{aligned}
$$

\footnotetext{
${ }^{6}$ Mendoza (1991), Correia, Neves, and Rebelo (1995), and Neumeyer and Perri (2005) show that specifying the utility function in line with GHH preferences improves the ability of the model to capture business-cycle dynamics. In section 3.2 , we analyze the performance of the model to reproduce some stylized facts for a sample of emerging economies.
} 
where $j \in[0,1]$ indicates the goods varieties and $\lambda>1$ is the elasticity of substitution among goods produced within a country.

The real exchange rate $R E X_{t}$ is defined as $R E X_{t}=\frac{S_{t} P_{t}^{*}}{P_{t}}$, where $S_{t}$ is the nominal exchange rate, domestic-currency price of foreign currency, and $P_{t}^{*} \equiv\left[\int_{0}^{1} P_{t}^{*}(j)^{1-\lambda} d j\right]^{1 /(1-\lambda)}$ is the aggregate price index for foreign country's consumption goods in foreign exchange rate. In contrast to most of the standard open-economy models, dynamics of $P_{t}^{*}$ are determined endogenously in our framework.

Households in the domestic economy participate in domestic and foreign financial markets: they lend to entrepreneurs in domestic currency, $D_{t}^{D}$, and they borrow from international financial markets in foreign currency, $D_{t}^{H}$, with a nominal interest rate of $i_{t}$ and $i_{t}^{*} \Psi_{D, t}$, respectively. We follow the existing literature in assuming that households need to pay a premium, $\Psi_{D, t}$, given by $\Psi_{D, t}=\frac{\Psi_{D}}{2}\left[\exp \left(\frac{S_{t} D_{t+1}^{H}}{P_{t} G D P_{t}}-\frac{S D^{H}}{P G D P}\right)-1\right]^{2}$ when they borrow from the rest of the world. ${ }^{7}$ Households own all home production and the importing firms and thus are recipients of profits, $\Pi_{t}$. Other sources of income for the representative household are wages $W_{t}$, interest earnings in domestic currency, and new borrowing net of interest payments on outstanding debts in foreign currency. Then, the representative household's budget constraint in period $t$ can be written as follows:

$$
\begin{aligned}
P_{t} C_{t} & +D_{t+1}^{D}+\left(1+i_{t-1}^{*}\right) \Psi_{D, t-1} S_{t} D_{t}^{H} \\
& =W_{t} H_{t}+\left(1+i_{t-1}\right) D_{t}^{D}+S_{t} D_{t+1}^{H}+\Pi_{t} .
\end{aligned}
$$

The representative household chooses sequences for $\left\{C_{t}, H_{t}\right.$, $\left.D_{t+1}^{D}, D_{t+1}^{H}\right\}_{t=0}^{\infty}$ in order to maximize its expected lifetime utility in (1) subject to the budget constraint in (3).

\footnotetext{
${ }^{7}$ We introduce this premium for households' foreign borrowing to maintain the stationarity in the economy's net foreign assets. In our calibration, the elasticity of the premium with respect to the debt is very close to zero $\left(\Psi_{D}=0.0075\right)$ so that the dynamics of the model are not affected by the premium. See SchmittGrohe and Uribe (2003) for detailed discussions on other methods that induce stationarity in small open-economy models. Note that it would not be necessary to introduce this premium when solving the model with a global solution, which is not the case in this paper.
} 


\subsection{Firms}

\subsubsection{Production Firms}

Each firm produces a differentiated good indexed by $j \in[0,1]$ using the production function:

$$
Y_{t}(j)=A_{t} N_{t}(j)^{1-\eta} K_{t}(j)^{\eta},
$$

where $A_{t}$ denotes total factor productivity common to all the production firms and it is assumed to follow an $\mathrm{AR}(1)$ process $\left(\ln \left(A_{t}\right)=\right.$ $\left.\rho_{A} \ln \left(A_{t-1}\right)+\varepsilon_{A}\right) . N_{t}(j)$ is the labor input, which is a composite of household labor, $H_{t}(j)$, and entrepreneurial labor, $H_{t}^{E}(j)$, defined as $N_{t}(j)=H_{t}(j)^{1-\Omega} H_{t}^{E}(j)^{\Omega} . K_{t}(j)$ represents capital provided by the entrepreneur, as we explore in the following subsection. Assuming that the price of each input is taken as given, the production firms minimize their costs subject to (4).

Firms have some market power and they segment domestic and foreign markets with local currency pricing, where $P_{H, t}(j)$ and $P_{X, t}(j)$ denote price in the domestic market (in domestic currency) and price in the foreign market (in foreign currency). Firms also face quadratic menu costs in changing prices expressed in the units-ofconsumption basket given by $\frac{\Psi_{i}}{2}\left(\frac{P_{i, t}(j)}{P_{i, t-1}(j)}-1\right)^{2}$ for different market destinations $i=H, X$. The presence of menu costs generates a gradual adjustment in the prices of goods in both markets, as suggested by Rotemberg (1982). The combination of local-currency pricing and nominal price rigidities implies that fluctuations in the nominal exchange rate have a smaller impact on export prices so that the exchange rate pass-through to export prices is incomplete in the short run.

As firms are owned by domestic households, the individual firm maximizes its expected value of future profits using the household's intertemporal rate of substitution in consumption, given by $\beta^{t} U_{c, t}$. The objective function of firm $j$ can thus be written as

$$
\begin{aligned}
& E_{o} \sum_{t=0}^{\infty} \frac{\beta^{t} U_{c, t}}{P_{t}}\left[P_{H, t}(j) Y_{H, t}(j)+S_{t} P_{X, t}(j) Y_{X, t}(j)-M C_{t} Y_{t}(j)\right. \\
& \left.\quad-P_{t} \sum_{i=H, X} \frac{\Psi_{i}}{2}\left(\frac{P_{i, t}(j)}{P_{i, t-1}(j)}-1\right)^{2}\right],
\end{aligned}
$$


where $Y_{H, t}(j)$ and $Y_{X, t}(j)$ represent domestic and foreign demand for the domestically produced good $j$. We assume that different varieties have the same elasticities in both markets, so that the demand for good $j$ can be written as

$$
Y_{i, t}(j)=\left(\frac{P_{i, t}(j)}{P_{i, t}}\right)^{-\lambda} Y_{i, t}, \text { for } i=H, X
$$

where $P_{H, t}$ is the aggregate price index for goods sold in the domestic market, as is defined earlier, and $P_{X, t}$ is the export price index given by $P_{X, t} \equiv\left[\int_{0}^{1} P_{X, t}(j)^{1-\lambda} d j\right]^{1 /(1-\lambda)}$.

\subsubsection{Importing Firms}

There is a set of monopolistically competitive importing firms, owned by domestic households, that buy foreign goods at prices $P_{X, t}^{*}$ (in local currency) and then sell them to the domestic market. They are also subject to a price adjustment cost with $\Psi_{M} \succeq 0$, the cost-ofprice-adjustment parameter, analogous to the production firms. This implies that there is some delay between exchange rate changes and the import price adjustments so that the short-run exchange rate pass-through to import prices is also incomplete.

\subsubsection{Unfinished-Capital-Producing Firms}

Let $I_{t}$ denote aggregate investment in period $t$, which is composed of domestic and final goods:

$$
I_{t}=\left[\alpha^{\frac{1}{\gamma}} I_{H, t}^{(\gamma-1) / \gamma}+(1-\alpha)^{\frac{1}{\gamma}} I_{M, t}^{(\gamma-1) / \gamma}\right]^{\gamma /(\gamma-1)}
$$

where the domestic and imported investment goods' prices are assumed to be the same as the domestic and import consumer goods' prices, $P_{H, t}$ and $P_{M, t}$. The new capital stock requires the same combination of domestic and foreign goods so that the nominal price of a unit of investment equals the price level, $P_{t}$.

Competitive firms use investment, $I_{t}$, as an input, and combine it with rented capital $K_{t}$ to produce unfinished capital goods. We assume that the marginal return to investment in terms of capital goods is decreasing in the amount of investment undertaken (relative 
to the current capital stock) due to the presence of adjustment costs, represented by $\frac{\Psi_{I}}{2}\left(\frac{I_{t}}{K_{t}}-\delta\right)^{2}$, where $\delta$ is the depreciation rate. ${ }^{8}$ Then, the production technology of the firms producing unfinished capital can be represented by $\Xi_{t}\left(I_{t}, K t\right)=\left[\frac{I_{t}}{K_{t}}-\frac{\Psi_{I}}{2}\left(\frac{I_{t}}{K_{t}}-\delta\right)^{2}\right] K_{t}$, which exhibits constant returns to scale so that the unfinished-capitalproducing firms earn zero profit in equilibrium. The stock of capital used by the firms in the economy evolves according to

$$
K_{t+1}=\left[\frac{I_{t}}{K_{t}}-\frac{\Psi_{I}}{2}\left(\frac{I_{t}}{K_{t}}-\delta\right)^{2}\right] K_{t}+(1-\delta) K_{t} .
$$

The optimality condition for the unfinished-capital-producing firms with respect to the choice of $I_{t}$ yields the following nominal price of a unit of capital $Q_{t}$ :

$$
\frac{Q_{t}}{P_{t}}=\left[1-\Psi_{I}\left(\frac{I_{t}}{K_{t}}-\delta\right)\right]^{-1} .
$$

\subsubsection{Entrepreneurs}

The key players of the model are entrepreneurs. They transform unfinished capital goods and rent them to the firms. They finance their investment by borrowing from domestic lenders and foreign lenders, channeled through perfectly competitive financial intermediaries. We denote variables for entrepreneurs borrowing from foreign resources with superscript $F$, and entrepreneurs borrowing from domestic resources with superscript $D$. In the absence of cost differences, entrepreneurs are indifferent between borrowing from domestic and foreign resources, and therefore the amounts borrowed from domestic and foreign resources are equal.

There is a continuum of entrepreneurs indexed by $k$ in the interval $[0,1]$. Each entrepreneur has access to a stochastic technology in transforming $K_{t+1}^{v}(k)$ units of unfinished capital into

\footnotetext{
${ }^{8}$ The presence of adjustment costs permits a variable price of capital and makes entrepreneurial net worth sensitive to asset-price variability as in Kiyotaki and Moore (1997). The recent general equilibrium literature states that incorporating the investment adjustment costs also improves the quantitative performance of the models along numerous dimensions. See, for example, Christiano, Eichenbaum, and Evans (2005).
} 
$\omega_{t+1}^{v}(k) K_{t+1}^{v}(k)$ units of finished capital goods, where $v$ is either $F$ or $D$. The idiosyncratic productivity $\omega_{t}(k)$ is assumed to be i.i.d. (across time and across firms), drawn from a distribution $F($.$) , with$ a probability distribution function of $f($.$) and E()=.1 .^{9}$

At the end of period $t$, each entrepreneur $k$ of type $v$ has net worth denominated in domestic currency, $N W_{t}^{v}(k)$. The budget constraints of the entrepreneurs for two different types are defined as follows:

$$
\begin{aligned}
& P_{t} N W_{t}^{F}(k)=Q_{t} K_{t+1}^{F}(k)-S_{t} D_{t+1}^{F}(k), \\
& P_{t} N W_{t}^{D}(k)=Q_{t} K_{t+1}^{D}(k)-D_{t+1}^{D}(k),
\end{aligned}
$$

where $D_{t+1}^{F}$ and $D_{t+1}^{D}$ denote foreign-currency-denominated debt and domestic-currency-denominated debt, respectively. Equations (10) and (11) simply state that capital financing is divided between net worth and debt.

Lenders have imperfect knowledge of the distribution of $\omega_{t+1}^{v}(k)$ ex ante. Following Cúrdia $(2007,2008)$ we specify the lenders' perception of $\omega_{t+1}^{v}(k)$ as given by $\omega_{t+1}^{v *}(k)=\omega_{t+1}^{v}(k) \varrho_{t}$, where $\varrho_{t}$ is the misperception factor over a given interval $[0,1] .{ }^{10}$ Further, the misperception factor, $\varrho_{t}$, is assumed to follow $\ln \left(\varrho_{t}\right)=\rho_{\varrho} \ln \left(\varrho_{t-1}\right)+\varepsilon_{\varrho}$, where $\rho_{\varrho}$ denotes the persistence parameter. We take the origin of the capital inflows as a change in lenders' perception regarding idiosyncratic productivity $\left(\varepsilon_{\varrho}\right) .^{11}$

Entrepreneurs observe $\omega_{t+1}^{v}(k)$ ex post, but the lenders can only observe it at a monitoring cost which is assumed to be a certain fraction $(\mu)$ of the return. This corresponds to the costly state verification (CVS) problem indicated by Gale and Hellwig (1985). The contracting problem identifies the capital demand of entrepreneurs, $K_{t+1}^{v}(k)$, and a cut-off value, $\bar{\omega}_{t+1}^{v}(k)$, such that the entrepreneur

\footnotetext{
${ }^{9}$ The idiosyncratic productivity is assumed to be distributed log-normally; $\log \left(\omega_{t}(k)\right) \sim N\left(\frac{-1}{2} \sigma_{\omega}^{2}, \sigma_{\omega}^{2}\right)$. This characterization follows Carlstrom and Fuerst (1997), Bernanke, Gertler, and Gilchrist (1999), and Gertler, Gilchrist, and Natalucci (2007).

${ }^{10}$ We assume that the perception factors for foreign and domestic lenders share the same dynamics. Given that there is no information friction between foreign and domestic lenders in our model, it is a plausible assumption.

${ }^{11} \mathrm{We}$ assume that when there is uncertainty about the underlying distribution, lenders take the worst-case scenario as the mean of the distribution of $\omega_{t+1}^{v}(k)$.
} 
maximizes their expected return subject to the participation constraints of the lender. ${ }^{12}$ The resulting first-order conditions are (see appendix 1)

$$
\begin{aligned}
& E_{t}\left[R_{t+1}^{K}\right]=E_{t}\left[\left(1+i_{t}^{*}\right)\left(1+\Phi_{t+1}^{F}\right)\right], \\
& E_{t}\left[R_{t+1}^{K}\right]=E_{t}\left[\left(1+i_{t}\right)\left(1+\Phi_{t+1}^{D}\right)\right],
\end{aligned}
$$

where $R_{t+1}^{K}$ is the ex post aggregate return on capital (averaged across entrepreneurs). Let $\left(1+\Phi_{t+1}^{F}(k)\right)$ and $\left(1+\Phi_{t+1}^{D}(k)\right)$ be default premiums on foreign and domestic borrowing for entrepreneur $k$, given by

$$
\begin{aligned}
1+ & \Phi_{t+1}^{F}(k) \\
= & {\left[\frac{z^{F \prime}\left(\bar{\omega}_{t+1}^{F}(k)\right)}{g^{F}\left(\bar{\omega}_{t+1}^{F}(k) ; \varrho_{t}\right) z^{F^{\prime}}\left(\bar{\omega}_{t+1}^{F}(k)\right)-z^{F}\left(\bar{\omega}_{t+1}^{F}(k)\right) g^{F^{\prime}}\left(\bar{\omega}_{t+1}^{F}(k) ; \varrho_{t}\right)}\right] } \\
& \times E_{t}\left\{\frac{S_{t+1}}{S_{t}}\right\}, \\
1+ & \Phi_{t+1}^{D}(k) \\
= & {\left[\frac{z^{D \prime}\left(\bar{\omega}_{t+1}^{D}(k)\right)}{\left.g^{D}\left(\bar{\omega}_{t+1}^{D}(k) ; \varrho_{t}\right) z^{D^{\prime}}\left(\bar{\omega}_{t+1}^{D}(k)\right)-z^{D}\left(\bar{\omega}_{t+1}^{D}(k)\right) g^{D^{\prime}\left(\bar{\omega}_{t+1}^{D}(k) ; \varrho_{t}\right)}\right]}\right.}
\end{aligned}
$$

where $z(\bar{\omega}(k))$ and $g(\bar{\omega}(k) ; \varrho)$ are the borrowers' and lenders' share of the total return, respectively. A greater use of external financing generates an incentive for entrepreneurs to take on more risky projects, which raises the probability of default. This, in turn, increases the default premium. Therefore, any shock that has a negative (positive)

\footnotetext{
${ }^{12}$ In the presence of aggregate uncertainty, the debt contracts with CVS that we focus on are known to be not optimal. In the contract, risk-averse (domestic and foreign) households are insured against aggregate uncertainty, as they receive non-state-contingent returns on their loans, channeled through financial intermediaries. This contract with perfect insurance, however, is not optimal because there could be a contract which provides a better insurance against aggregate uncertainty (by providing a state-contingent rate of return to households, but compensating them for this) and allows a debt contract with CVS to entrepreneurs. Note that the contract could be optimal for sufficiently risk-averse households as conjectured by Bernanke, Gertler, and Gilchrist (1999).
} 
impact on the entrepreneurs' net worth increases (decreases) their leverage, resulting in a higher (lower) default premium.

We follow the existing literature in assuming that a proportion of entrepreneurs dies in each period to be replaced by newcomers. ${ }^{13}$ This assumption guarantees that self-financing never occurs and borrowing constraints on debt are always binding. As presented in Carlstrom and Fuerst (1997), the investment and monitoring technologies exhibiting constant returns to scale imply linearity and symmetry of the contracting problem such that all entrepreneurs face the same financial contract specified by the cut-off value and the external finance premium. This allows us to specify the rest of the model in aggregate terms.

One of the key mechanisms of the model is the evolution of net worth, $N W_{t}^{v}$, which is a function of entrepreneurs' capital net of borrowing costs carried over the previous period and entrepreneurial wage. Denoting the fraction of entrepreneurs who survive each period by $\vartheta$, we express the net worth as follows:

$$
P_{t} N W_{t}^{v}=\vartheta\left[R_{t}^{K} Q_{t-1} K_{t}^{v} z^{v}\left(\bar{\omega}_{t}^{v}\right)\right]+W_{t}^{v E}
$$

The total capital in the economy is $K_{t}=K_{t}^{F}+K_{t}^{D}$. Because of investment adjustment costs and incomplete capital depreciation, entrepreneurs' return on capital, $R_{t+1}^{K}$, is not identical to the rental rate of capital, $R_{t}$. In fact, $R_{t+1}^{K}$ is the sum of the rental rate on capital paid by the firms that produce final consumption goods, the rental rate on used capital from the firms that produce unfinished capital goods, and the value of the non-depreciated capital stock, after the adjustment for the fluctuations in the asset prices $\left(\frac{Q_{t+1}}{Q_{t}}\right)$ :

$$
\begin{aligned}
& E_{t}\left[R_{t+1}^{K}\right]=E_{t}\left[\frac{R_{t+1}}{Q_{t}}\right. \\
& \left.\quad+\frac{Q_{t+1}}{Q_{t}}\left\{(1-\delta)+\Psi_{I}\left(\frac{I_{t+1}}{K_{t+1}}-\delta\right) \frac{I_{t+1}}{K_{t+1}}-\frac{\Psi_{I}}{2}\left(\frac{I_{t+1}}{K_{t+1}}-\delta\right)^{2}\right\}\right] .
\end{aligned}
$$

\footnotetext{
${ }^{13}$ See, for example, Carlstrom and Fuerst (1997) and Gertler, Gilchrist, and Natalucci (2007).
} 


\subsection{Financial Intermediaries and Macroprudential Policy}

There exists a continuum of perfectly competitive financial intermediaries which collect deposits from households and loan the money out to entrepreneurs in each period. They also receive capital inflows from the foreign economy in the form of loans to domestic entrepreneurs. The sum of deposits and capital inflows makes up the total supply of loanable funds. The zero-profit condition on financial intermediaries implies that the lending rates are just equal to $E_{t}\left[\left(1+i_{t}^{*}\right)\left(1+\Phi_{t+1}^{F}\right)\right]$ and $E_{t}\left[\left(1+i_{t}\right)\left(1+\Phi_{t+1}^{D}\right)\right]$ in the absence of macroprudential measures.

Either in the form of capital requirements or loan-to-value ceiling, or some other type, macroprudential policy entails higher costs for financial intermediaries. Rather than deriving the impact of a particular type of macroprudential measure on the borrowing cost, we follow Kannan, Rabanal, and Scott (2009) and focus on a generic case where macroprudential measures lead to an additional cost to financial intermediaries. These costs are then reflected to borrowers in the form of higher interest rates. ${ }^{14}$ The increase in the lending rates brought by (broad) macroprudential measures is called the "regulation premium" and is a function of nominal credit growth. ${ }^{15}$

In the presence of macroprudential regulations, the spread between lending rate and policy rate is affected by both the default premium and the regulation premium. Hence, the lending costs for foreign borrowing and domestic borrowing, equations (12) and (13), become

$$
\begin{aligned}
& E_{t}\left[R_{t+1}^{K}\right]=E_{t}\left[\left(1+i_{t}^{*}\right)\left(1+\Phi_{t+1}^{F}\right)\left(1+R P_{t}\right)\right], \\
& E_{t}\left[R_{t+1}^{K}\right]=E_{t}\left[\left(1+i_{t}\right)\left(1+\Phi_{t+1}^{D}\right)\left(1+R P_{t}\right)\right],
\end{aligned}
$$

\footnotetext{
${ }^{14}$ By adopting a more elaborate banking sector, Angeloni and Faia (2009), Angeloni, Faia, and Lo Duca (2010), and Gertler and Karadi (2011) show that macroprudential measures in fact lead to an increase in the cost of borrowing. In an open-economy framework, following a similar approach would make the model hardly traceable. Therefore, we use a simpler specification here and leave analysis of frictions related to financial intermediaries for future work.

${ }^{15}$ See Borgy, Clerc, and Renne (2009), Borio and Drehman (2009), and Gerdesmeier, Roffia, and Reimers (2009) for discussions on the potential role of nominal credit growth in a regulation tool.
} 
where $R P_{t}$ is the regulation premium, which is defined in the baseline case as a function of the aggregate nominal credit growth:

$$
R P_{t}=\Psi\left(\frac{D_{t}}{D_{t-1}}-1\right)
$$

where $D_{t}=S_{t} D_{t}^{F}+D_{t}^{D}$. In this definition of broad macroprudential policy, it is implicit that the policy objective is defined in terms of aggregate credit activity. In the case of macroprudential measures that discriminate against foreign liabilities (macroprudential capital controls), the regulation premium only applies to foreign borrowing (18) and the macroprudential policy instrument $\left(R P_{t}\right)$ is defined only in terms of nominal foreign credit growth.

\subsubsection{Monetary Policy}

In the baseline calibration, we adopt a standard formulation for the structure of monetary policymaking. We assume that the interest rate rule is of the following form:

$$
1+i_{t}=\left[(1+i)\left(\pi_{t}\right)^{\epsilon_{\pi}}\left(Y_{t} / Y\right)^{\epsilon_{Y}}\right]^{\varpi}\left[1+i_{t-1}\right]^{1-\varpi},
$$

with $\left\{\epsilon_{\pi}\right\} \in(1, \infty],\left\{\epsilon_{Y}\right\} \in(0, \infty]$, and $\varpi \in[0,1]$. In $(21) \varpi$ is the interest rate smoothing parameter, $i$ and $Y$ denote the steady-state level of nominal interest rate and output, and $\pi_{t}$ is the CPI inflation. We start with an initial set of values for $\epsilon_{\pi}, \epsilon_{Y}$, and $\varpi$ in the calibration. In the optimal simple rules, however, we numerically compute the optimal values of $\epsilon_{\pi}$ and $\epsilon_{Y}$ (as well as the macroprudential rule coefficient $\Psi$ ) that maximize the welfare measure derived from households' utility function (further discussion is presented below).

\section{Calibration, Solution Strategy, and Model Evaluation}

In this section we first describe the calibration of the model and the model solution. We then discuss the model's ability to fit the data for typical emerging, open economies.

\subsection{Calibration and Solution Strategy}

The parameters for consumption, production, and entrepreneurial sectors are assumed to be identical for the domestic economy and 
Table 1. Parameter Values for Consumption, Production, and Entrepreneurial Sectors

\begin{tabular}{|l|l|}
\hline$n=0.1$ & Relative Size of the Domestic Economy \\
$\beta=0.99$ & Discount Factor \\
$\sigma=2$ & Inverse of the Intertemporal Elasticity of Substitution \\
$\varphi=0.25$ & Utility Weight of Labor \\
$\gamma=1$ & Frisch Elasticity of Labor Supply \\
$v=0.35$ & Elasticity of Substitution between Domestic and \\
$\eta=0.35$ & Foreign Goods \\
$\lambda=11$ & Degree of Openness \\
$\delta=0.025$ & Share of Capital in Production \\
$\Omega=0.01$ & Elasticity of Substitution between Domestic Goods \\
$\Psi_{I}=12$ & Share of Entrepreneurial Labor \\
$\Psi_{D}=0.0075$ & Investment Adjustment Cost \\
$\Psi_{i}, \Psi_{M}=120$ & Responsiveness of Households' Premium to Debt/GDP \\
$\varpi=0.5$ & Price Adjustment Costs for $i=H, X$ \\
$\rho_{\varrho}=0.5$ & Degree of Interest Rate Smoothing \\
$\rho_{A}=0.8$ & Persistence of the Perception Shock \\
$\Phi_{t}=0.02$ & Persistence of the Productivity Shock \\
$\mu=0.2$ & Default Premium \\
$\kappa=0.3$ & Monitoring Cost \\
\hline
\end{tabular}

the rest of the world (table 1). One exception is the relative size parameter, $n$, which is set to 0.1 so that the domestic economy is relatively small. We set the discount factor, $\beta$, at 0.99 , implying a riskless annual return of approximately 4 percent in the steady state (time is measured in quarters). Following Gertler and Karadi (2011), we set the inverse of the elasticity of intertemporal substitution $(\sigma)$ equal to 2 , the inverse of the elasticity of labor supply $(\varphi)$ to $1 / 3$, and the weight of labor utility $(\chi)$ to $1 / 4$. We set openness, $v$, to be 0.35 , which is within the range of the values used in the literature. ${ }^{16}$ The share of capital in production, $\eta$, is taken to

\footnotetext{
${ }^{16}$ The values set in the literature for openness range between 0.25 (Cook 2004; Elekdag and Tchakarov 2007) and 0.5 (Gertler, Gilchrist, and Natalucci 2007). We choose to set a middle value of the range.
} 
be 0.35 , consistent with other studies. ${ }^{17}$ Following Devereux, Lane, and $\mathrm{Xu}$ (2006), the elasticity of substitution between differentiated goods of the same origin, $\lambda$, is taken to be 11, implying a flexibleprice equilibrium markup of 1.1. Price adjustment cost is assumed to be 120 for all sectors. The quarterly depreciation rate $(\delta)$ is 0.025 . Similar to Gertler, Gilchrist, and Natalucci (2007), we set the share of entrepreneurs' labor, $\Omega$, at 0.01 , implying that 1 percent of the total wage bill goes to the entrepreneurs. We set the steady-state leverage ratio and the value of the quarterly default premium at 0.3 and 200 basis points, respectively, reflecting the historical average of emerging-market economies within the last decade. ${ }^{18}$ The monitoring cost parameter, $\mu$, is taken as 0.2 as in Devereux, Lane, and $\mathrm{Xu}(2006)$. The degree of interest rate smoothing parameter $(\varpi)$ is chosen as 0.5 . $\rho_{\varrho}$ is assumed to be 0.5 , so that it takes nine quarters for the shock to die away. ${ }^{19}$

We analyze the macroeconomic impact of an unanticipated (temporary) favorable shock to (both domestic and foreign) investors' perception regarding productivity of entrepreneurs - an "optimism" shock. In particular, we give a 1 percent positive shock to the (log of) misperception factor $\left(\ln \left(\varrho_{t}\right)\right) .{ }^{20}$ We present responses of the economy under several monetary and macroprudential policy options, namely (i) Taylor rule, (ii) Taylor rule with broad macroprudential policy, (iii) Taylor rule with macroprudential capital controls, (iv) fixed exchange rate regime, (v) fixed exchange rate regime with broad macroprudential policy, and (vi) fixed exchange rate regime with macroprudential capital controls. Table 2 represents the

${ }^{17}$ See, for example, Cespedes, Chang, and Velasco (2004) and Elekdag and Tchakarov (2007).

${ }^{18}$ This is the average number for emerging Americas, emerging Asia, and emerging Europe between 2000 and 2010. Worldscope data (debt as a percentage of assets - data item WS 08236) is used for the leverage ratio. The default premium is calculated as the difference between the lending and the policy rate for emerging-market countries, where available, using data from Haver Analytics for the same time period. Variations in these parameters do not affect our results qualitatively.

${ }^{19}$ We carry out several sensitivity analyses in order to assess robustness of our results under the benchmark calibration. To conserve space, we do not report these results, but they are available upon request.

${ }^{20}$ The optimism shock brings about a 1.25 and 2 percent decline in domestic and foreign default premiums, respectively, under the baseline calibration, and a surge in capital inflows by about 1 percent of output. 
Table 2. Parameters of the Policy Rules

\begin{tabular}{|l|c|c|c|}
\hline & \multicolumn{2}{|c|}{ Taylor Rule } & $\begin{array}{c}\text { Macroprudential } \\
\text { Rule }\end{array}$ \\
\cline { 2 - 4 } & $\begin{array}{c}\text { Inflation Rate } \\
\left(\boldsymbol{\epsilon}_{\boldsymbol{\pi}}\right)\end{array}$ & $\begin{array}{c}\text { Output Gap } \\
\left(\boldsymbol{\epsilon}_{\boldsymbol{y}}\right)\end{array}$ & $\begin{array}{c}\text { Credit Growth } \\
(\boldsymbol{\Psi})\end{array}$ \\
\hline $\begin{array}{l}\text { Taylor Rule (TR) } \\
\text { TR with Broad } \\
\text { Macroprudential }\end{array}$ & 1.5 & 0.5 & 0 \\
Policy (BMP) & 1.5 & 0.5 & 0.5 \\
TR with & & & \\
Macroprudential & 1.5 & 0.5 & 0.5 \\
Capital Controls & & & $\begin{array}{c}\text { (on foreign } \\
\text { (MCC) }\end{array}$ \\
Fixed Exchange & & & \\
Rate (FER) & - & - & - \\
FER with BMP & - & - & 0.5 \\
FER with MCC & - & - & $\begin{array}{c}\text { (on foreign } \\
\text { credit) }\end{array}$ \\
& & & \\
\hline
\end{tabular}

parameterization for monetary and macroprudential policy instruments under alternative policy frameworks.

In the solution, we first transform the model to reach a stationary representation where the steady state exists. We then solve the model numerically up to a second-order approximation around the non-stochastic steady state using Sims $(2005) .{ }^{21}$

\subsection{Model Evaluation}

In our analysis, we eliminate several other shocks used in the literature and instead focus on the financial shock that derives our policy results. Therefore, despite the fact that the model has a potential to have reasonable implications in terms of predictions

\footnotetext{
${ }^{21}$ The non-stochastic steady state of the model is solved numerically in MAT$\mathrm{LAB}$, and then the second-order approximation of the model and the stochastic simulations are computed using Michel Juillard's software Dynare. Details of the computation of the non-stochastic steady state and the stationary model equations are available upon request.
} 
of macroeconomic variables, we cannot expect that the model will match in all dimensions the data. However, to generate confidence in the model's ability to correctly capture dynamics, and on the proposed calibration of the parameters' values, we compare movements and co-movements of some key variables.

Following Neumeyer and Perri (2005), we report business-cycle statistics for Argentina, Brazil, Korea, Mexico, and the Philippines. We use data over the 1995:Q1-2010:Q4 period, obtained from the International Financial Statistics (IFS) of the International Monetary Fund. All data variables are reported in percent deviations from the HP-filtered trend, and all model variables are reported in percent deviations from the steady state. One exception is the current account, which is reported as a share of GDP both in data and in the model variables.

We report the data and the simulated moments under the optimism shock in table 3 . The model does quite well in getting the dynamics of the variables. Despite the fact that we focus on only one shock, standard deviations of data and model variables are reasonably close. The relative standard deviations of variables with respect to standard deviation of output also match well with the model-based results. However, the correlations of output with consumption, investment, and current account in the model are higher than those in the data.

\section{Interactions between Macroprudential and Monetary Policies When Capital Inflows Surge}

In this section, we explore how an unanticipated (temporary) favorable shock to the investors' perception of the entrepreneurs' productivity is transmitted to the rest of the economy and the role of monetary and macroprudential policies in mitigating the impact of the shock. When the investors become more optimistic about the ability of entrepreneurs to pay their debt, lending to domestic entrepreneurs becomes less risky, and the default premium declines on impact. As the cost of borrowing declines, entrepreneurs increase their use of external financing by undertaking more projects. Higher borrowing also increases the future supply of capital and hence brings about a rise in consumption and output. Overall, following the capital inflows surge, the economy experiences higher demand 
Table 3. Business Cycles in Emerging Economies: Data vs. Model

\begin{tabular}{|c|c|c|c|c|}
\hline \multicolumn{5}{|c|}{ Standard Deviations (in \%) } \\
\hline & Output & Consumption & Investment & $\begin{array}{l}\text { Current } \\
\text { Account }\end{array}$ \\
\hline Argentina & 4.58 & 5.95 & 12.94 & 1.01 \\
\hline Brazil & 1.94 & 1.95 & 4.89 & 2.19 \\
\hline Korea & 2.57 & 3.52 & 5.49 & 3.40 \\
\hline Mexico & 2.55 & 3.57 & 6.98 & 5.80 \\
\hline Philippines & 2.58 & 1.93 & 7.03 & 4.24 \\
\hline Average & 2.84 & 3.38 & 7.47 & 3.33 \\
\hline Model & 3.12 & 3.56 & 12.34 & 3.24 \\
\hline \multicolumn{5}{|c|}{ Standard Deviations Relative to Output } \\
\hline & Output & Consumption & Investment & $\begin{array}{l}\text { Current } \\
\text { Account }\end{array}$ \\
\hline Argentina & 1.0 & 1.30 & 2.83 & 0.22 \\
\hline Brazil & 1.0 & 1.01 & 2.52 & 1.13 \\
\hline Korea & 1.0 & 1.37 & 2.14 & 1.32 \\
\hline Mexico & 1.0 & 1.40 & 2.74 & 2.27 \\
\hline Philippines & 1.0 & 0.75 & 2.72 & 1.64 \\
\hline Average & 1.0 & 1.16 & 2.59 & 1.32 \\
\hline Model & 1.0 & 1.14 & 3.96 & 1.04 \\
\hline \multicolumn{5}{|c|}{ Correlations with Output and Autocorrelation of Output } \\
\hline & $\rho(C, Y)$ & $\rho(I, Y)$ & $\rho(C A, Y)$ & $\rho\left(Y_{t}, Y_{t-1}\right)$ \\
\hline Argentina & 0.92 & 0.83 & -0.54 & 0.83 \\
\hline Brazil & 0.77 & 0.38 & -0.03 & 0.35 \\
\hline Korea & 0.87 & 0.86 & -0.72 & 0.80 \\
\hline Mexico & 0.78 & 0.85 & -0.45 & 0.82 \\
\hline Philippines & 0.82 & 0.10 & 0.01 & 0.78 \\
\hline Average & 0.83 & 0.61 & -0.35 & 0.72 \\
\hline Model & 0.91 & 0.92 & -0.90 & 0.65 \\
\hline
\end{tabular}


and inflation pressures, along with a credit growth boom. ${ }^{22}$ In that case, macroprudential policies which directly counteract easing in the lending standards might mitigate the impact of the shock and therefore improve macroeconomic and financial stability.

The exchange rate regime is an important determinant of how the shocks transmit to the rest of the economy and the role of macroprudential policies. The surge in capital inflows increases the supply of foreign debt and demand for domestic assets, and exchange rate appreciates under the Taylor-type monetary policy rule. The exchange rate appreciation reduces the impact of the shock through mainly two channels. First, the appreciation brings a downward pressure on the CPI-based inflation through lower imported good prices. Second, the rest of the world's demand for domestic goods decreases as they become relatively more expensive. Moreover, imports increase on account of income and exchange rate effects following the shock. Hence, the trade balance deteriorates, which reduces the output response of the shock. ${ }^{23}$ Under a fixed exchange rate regime, however, the adjustment on the external balance has to rely on an increase in the domestic price level. Interest rates remain low, and the responses of consumption, output, and inflation are more pronounced. Given the absence of an independent policy tool, the use of macroprudential policies can provide a mechanism for promoting macroeconomic stability under the fixed exchange rate regime.

We first focus on the standard Taylor rule and the Taylor rule with broad macroprudential policy. Next, we consider broad macroprudential policy and macroprudential measures on foreign liabilities (macroprudential capital controls). Then, we analyze broad and foreign liability-specific macroprudential policies under the fixed exchange rate regime. Note that we just present a positive description of the dynamics under alternative monetary and macroprudential policies in this section, without any judgment in

${ }^{22}$ These are in line with the experience of several emerging-market countries in capital inflows episodes (Cardarelli, Elekdag, and Kose 2010).

${ }^{23}$ The exchange rate appreciation has also an indirect impact on inflation and output through its impact on debt dynamics. The unanticipated change in the exchange rate creates a (positive) balance sheet effect for the foreigncurrency-borrowing entrepreneurs through a decline in the real debt burden. This exacerbates the effects of the shock on debt dynamics, and hence on output and inflation. However, this indirect impact is relatively small under reasonable parameterizations in our model. 
terms of optimality of one policy over another. We leave the normative policy analysis to section 5 .

\subsection{Can Macroprudential Measures Complement Monetary Policy?}

Figure 1 shows the responses to the optimism shock under two different alternative policy options: the standard Taylor rule and the Taylor rule with broad macroprudential policy.

In the first-baseline - scenario, the Taylor rule, output and inflation increase by about 0.6 and 0.8 percent on impact following the surge in capital inflows. Both domestic and foreign credit rise up to 1.5 percent and exchange rate appreciates, which limits the inflation pressures. Asset prices also increase by more than 2.5 percent after the shock. Under the inflation-targeting regime, the policy rate is raised by about 75 basis points in response to the overheating in the economy. The higher policy rates partially offset the impact of the lower default premium on lending rates and stabilize output as consumption becomes more costly. Eventually, the stabilization of demand helps to reduce inflation, and the economy goes back to normalcy.

In the second scenario, the Taylor rule with broad macroprudential policy, policymakers also adopt a macroprudential tool that directly counteracts the easing of the lending standards (in both foreign and domestic lending) and thus the financial accelerator effect. The responsiveness of the macroprudential instrument to nominal credit growth is set at 0.5 (table 2). In that case, both domestic debt and foreign debt increase less than in the first scenario (by about 0.5 percent at the peak), and the aggregate credit growth is about 30 percent slower. The increase in capital inflows and asset prices is also lower in the presence of macroprudential measures. The responses of output and inflation are therefore about 25 percent more muted than the responses under the baseline scenario.

The experiment implies that macroprudential policies may help monetary policy in providing macroeconomic and financial stability. However, it is not clear from the analysis whether there would still be a role for macroprudential measures if monetary policy rule is set in an "optimal" way, instead of ad hoc parameters. This question is addressed in section 5 . 


\section{Figure 1. A Positive Financial Shock: Taylor Rule and Broad Macroprudential Policy (percent deviations from the steady state)}
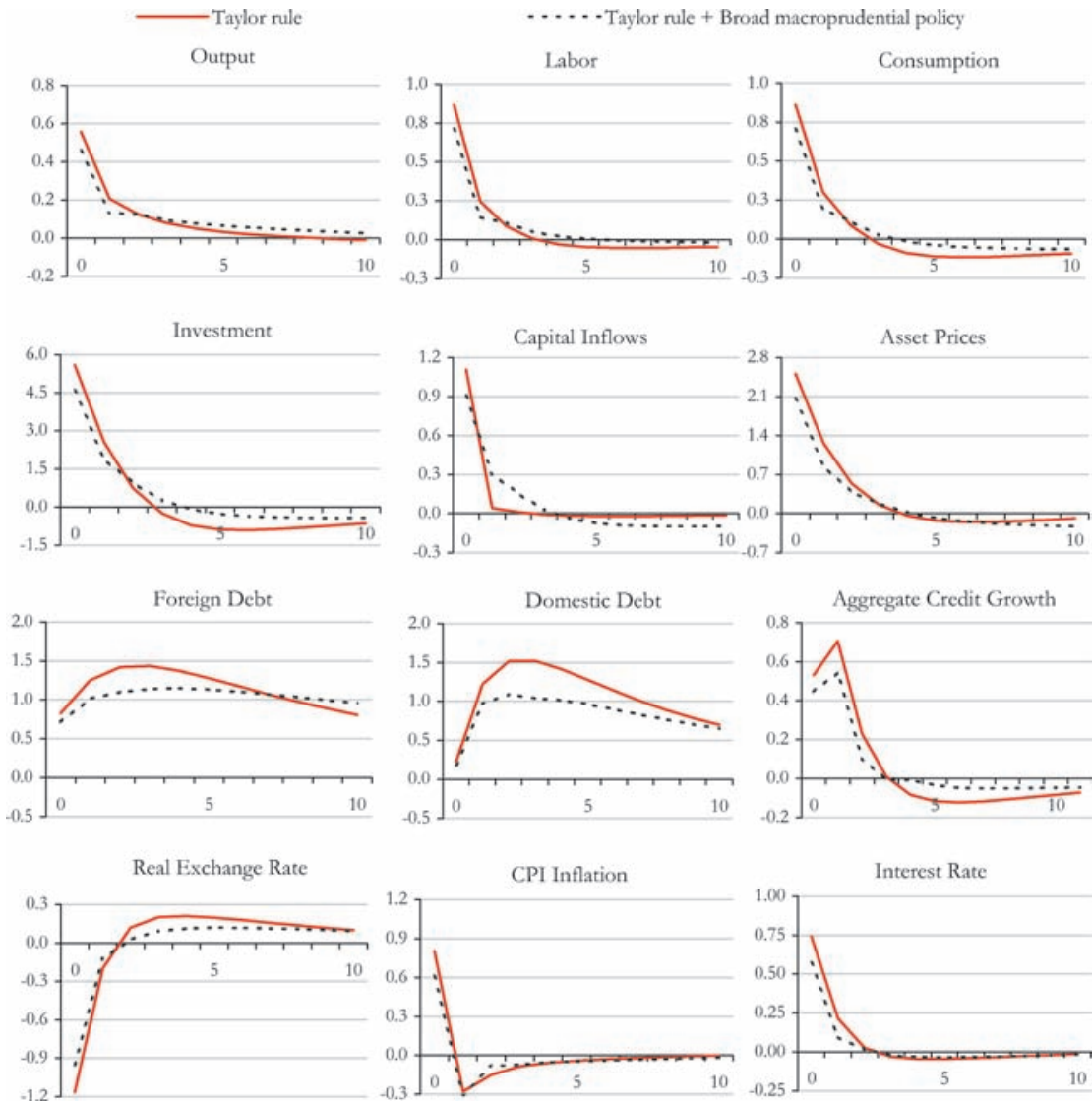

Notes: The figures show the impact of a 1 percent positive shock to the perception of investors regarding the productivity of domestic entrepreneurs. The variables are presented as log-deviations from the steady state (except for interest rate), multiplied by 100 to have an interpretation of percentage deviations.

\subsection{How Effective Are Macroprudential Measures on Foreign Liabilities (Macroprudential Capital Controls)?}

We next look at the policy mix which combines the Taylor rule with macroprudential capital controls (figure 2). In this case, the 
Figure 2. A Positive Financial Shock: Broad Macroprudential Policy and Macroprudential Capital Controls under Taylor Rule (percent deviations from the steady state)
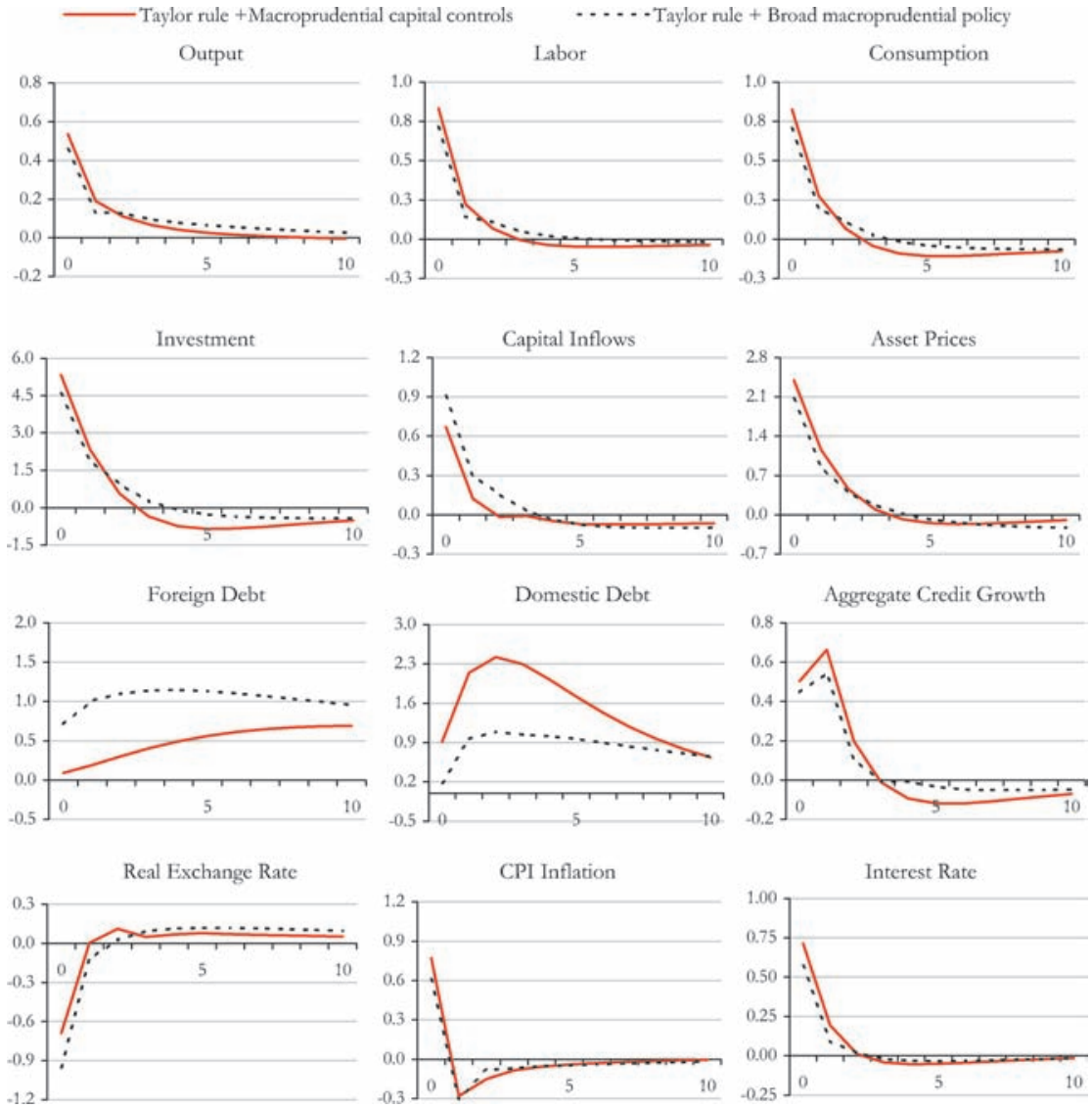

Notes: The figures show the impact of a 1 percent positive shock to the perception of investors regarding the productivity of domestic entrepreneurs. The variables are presented as log-deviations from the steady state (except for interest rate), multiplied by 100 to have an interpretation of percentage deviations.

regulation premium only applies to the loans from international resources, equation (18), and the regulation premium is defined as a function of the nominal foreign credit growth. Under that scenario, the effect of the financial shock on foreign borrowing is less 
pronounced; the surge in the capital flows is almost two-thirds of the baseline case, and the exchange rate appreciates less. Nevertheless, the policy measure fails to achieve its very first objective of promoting financial stability - it only brings a shift from foreign loans to domestic loans, leaving the aggregate credit growth nearly unchanged compared with the baseline scenario (figure 1). ${ }^{24}$

If the shock comes initially from increased optimism of the foreign investors only, macroprudential capital controls could help to alleviate financial instability risk at its source, making broad measures redundant. In this case, the performance of macroprudential capital controls improves upon a more general macroprudential approach. In practice, however, the perceptions of domestic and foreign investors are unlikely to deviate from each other for a prolonged period, hence we assume away the possibility of a foreign- (or domestic-) investors-specific perception shock.

\subsection{Does the Exchange Rate Regime Matter for the Role of Macroprudential Policies?}

We next analyze the dynamic responses of the macroeconomic variables to the financial shock under a fixed exchange rate regime with and without broad macroprudential policy (figure 3). Under the fixed exchange rate regime, consumption, output, and inflation increase by about 25 percent more than under the Taylor rule (figure 1) where the nominal currency appreciation helps to limit the overheating and inflation pressures. The increase in asset prices with the fixed exchange rate regime is also about 20 percent higher than the response with the Taylor rule. The responses of foreign and domestic credit, however, are more muted due to the absence of the positive impact of exchange rate appreciation on the net worth of entrepreneurs, which would make borrowing cheaper by lowering the default premium under the flexible exchange rate regime.

\footnotetext{
${ }^{24}$ Macroprudential measures could also be applied to domestic borrowing only. For example, a number of emerging-market countries such as China, Korea, and Turkey have recently increased reserve requirement rates in an effort to tighten monetary conditions. Nevertheless, similarly to the case of capital controls, such a measure is likely to bring a shift in the source of borrowing from domestic to foreign markets, causing only a limited change in the aggregate credit growth.
} 
Figure 3. A Positive Financial Shock: Fixed Exchange Rate Regime and Broad Macroprudential Policy (percent deviations from the steady state)
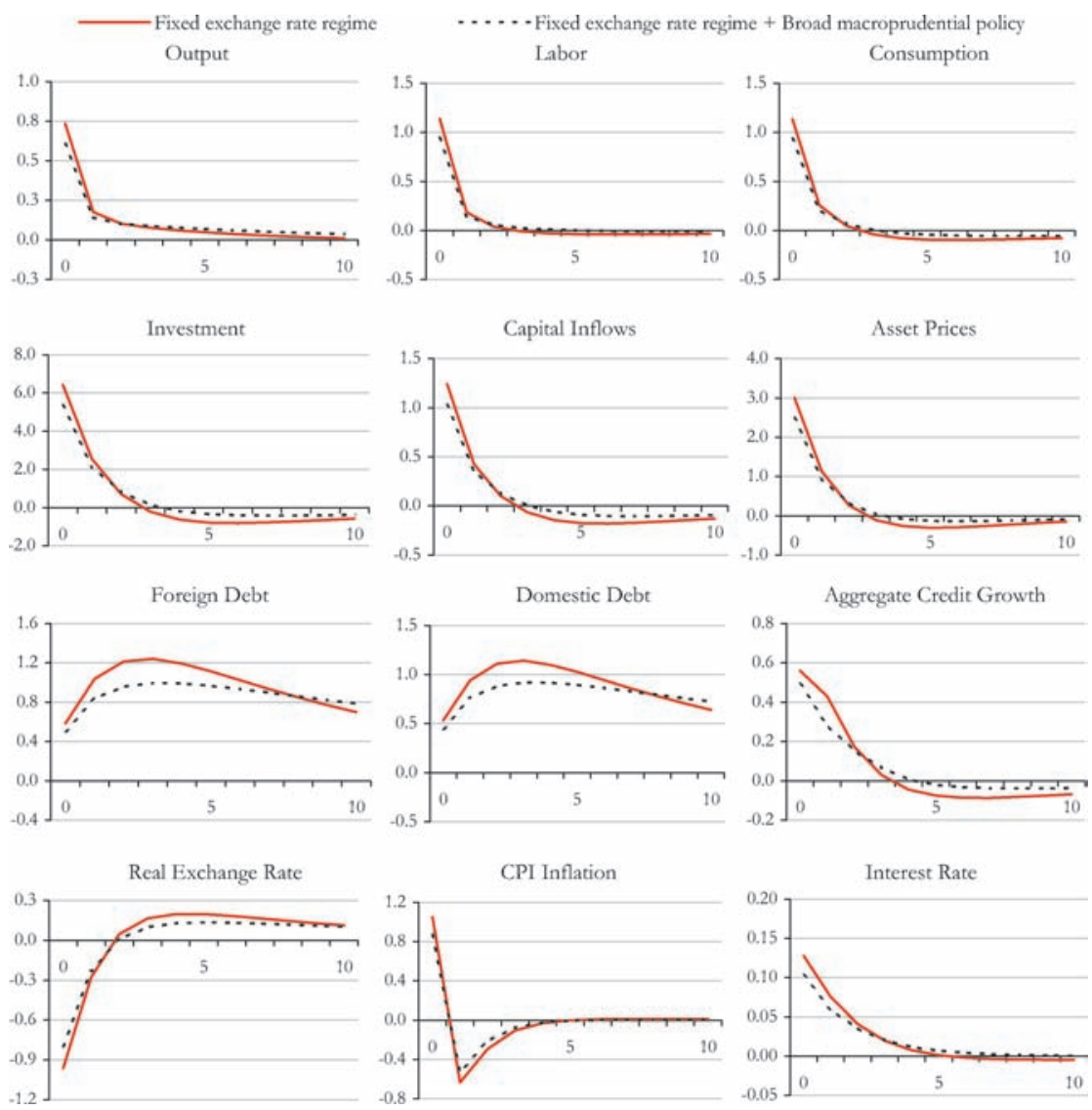

Notes: The figures show the impact of a 1 percent positive shock to the perception of investors regarding the productivity of domestic entrepreneurs. The variables are presented as log-deviations from the steady state (except for interest rate), multiplied by 100 to have an interpretation of percentage deviations.

The qualitative impact of macroprudential policy under the fixed exchange rate regime is virtually identical to that in the case of the flexible exchange rate economy under the Taylor rule. With broad macroprudential policy, introducing a regulation premium increases 
the effective lending rate for foreign and domestic entrepreneurs and reduces the impact of the shock on credit growth and investment. Overall, under the fixed exchange rate regime, macroeconomic and financial stability implications of the shock are more muted when broad macroprudential policy is in place.

We further investigate the impact of macroprudential capital controls under the fixed exchange rate regime (figure 4). Similar to the case under the flexible exchange rate regime, the macroprudential capital controls are less effective than the broad macroprudential measures in our simulations. Under the fixed exchange rate regime, the responses of capital inflows and real exchange rate are smaller with macroprudential capital controls, but the responses of asset prices, output, and inflation are almost identical to the case without a macroprudential tool.

\section{Welfare Evaluation of Alternative Policy Options and the Optimal Policy}

To provide a full assessment of optimal policy design, we consider welfare gains from responding to financial market developmentsproxied by nominal credit growth in our experiments - through macroprudential policy instruments and compute the optimal degree of intervention. We take the utility function of consumers as the objective.

Following Faia and Monacelli (2007) and Gertler and Karadi (2011), we start by expressing the household utility function recursively:

$$
V_{t}=U\left(C_{t}, H_{t}\right)+\beta E_{t} V_{t+1}
$$

where $V_{t} \equiv E_{0} \sum_{t=0}^{\infty} \beta^{t} U\left(C_{t}, H_{t}\right)$ denotes the utility function. We take a second-order approximation of $V_{t}$ around the deterministic steady state. Using the second-order solution of the model, we then calculate $V_{t}$ in each of the separate cases of monetary and macroprudential policies. ${ }^{25}$ We do the comparison among alternative policies

\footnotetext{
${ }^{25}$ It is rather standard in the literature to calculate the welfare using a secondorder approximation to utility function. See Schmitt-Grohe and Uribe (2007) for a lengthy discussion on the topic.
} 
Figure 4. A Positive Financial Shock: Broad Macroprudential Policy and Macroprudential Capital Controls under Fixed Exchange Rate Regime (percent deviations from the steady state)
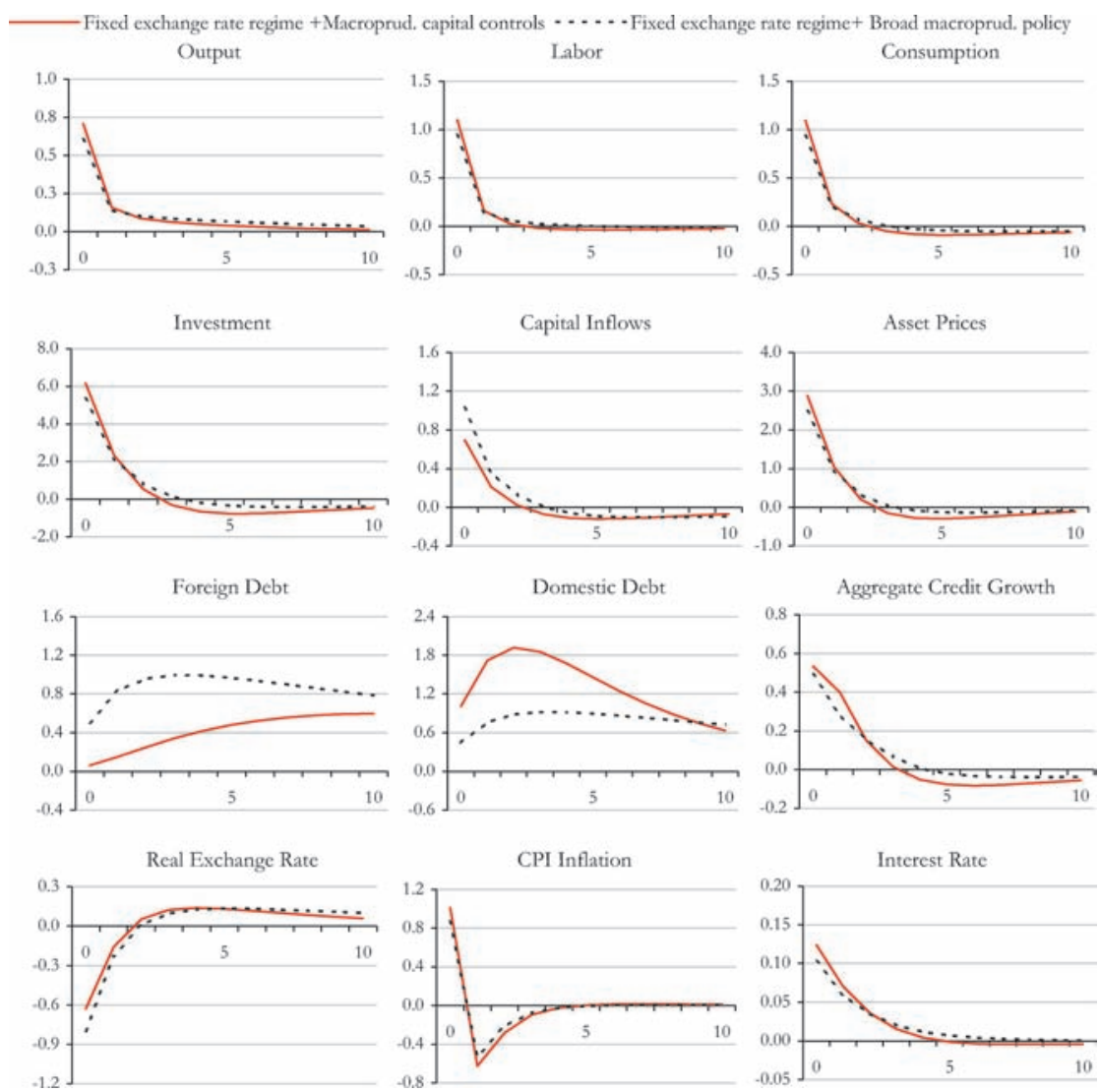

Notes: The figures show the impact of a 1 percent positive shock to the perception of investors regarding the productivity of domestic entrepreneurs. The variables are presented as log-deviations from the steady state (except for interest rate), multiplied by 100 to have an interpretation of percentage deviations.

in terms of a consumption equivalent, $\Upsilon$, given by the fraction of consumption required to equate welfare under any given monetary and macroprudential policies, $V_{t}^{*}$, to the welfare under the optimal Taylor rule type monetary policy, $V_{t}^{\text {opt }}$. In our specification of the utility function, and under $\sigma=2$, 


$$
\Upsilon=\left(\frac{\left(V_{t}^{o p t}-V_{t}\right)(1-\beta)\left(C-\frac{\chi}{1+\varphi} H^{1+\varphi}\right)^{2}}{C\left(1-\left(V_{t}^{o p t}-V_{t}\right)(1-\beta)\left(C-\frac{\chi}{1+\varphi} H^{1+\varphi}\right)\right)}\right),
$$

where the variables without subscripts are the steady-state values of the corresponding variables. As presented in table $4, \Upsilon$ is a measure of welfare loss in units of steady-state consumptiona higher $\Upsilon$ implies a higher welfare loss and hence indicates that the policy is less desirable policy from a welfare point of view. To find the optimal simple monetary and macroprudential policy rules, we then search numerically in the grid of parameters $\left\{\epsilon_{\pi}, \epsilon_{y}, \Psi\right\}$ that optimize $V_{t}$ in response to the financial shock. Table 5 shows the optimized monetary and macroprudential policy parameters.

The main result that emerges from this analysis is that there exists a positive welfare effect of using broad macroprudential policies. With the calibrated parameters, introducing broad macroprudential measures decreases the welfare loss by about 0.8 percent of steady-state consumption under a Taylor-rule type monetary policy

\section{Table 4. Welfare Results under a Financial Shock, in Percent of Steady-State Consumption}

\begin{tabular}{|l|c|}
\hline & $\Upsilon$ \\
\hline Taylor Rule (TR) & 1.19 \\
TR with Broad Macroprudential Policy (BMP) & 0.43 \\
TR with Macroprudential Capital Controls (MCC) & 1.06 \\
Fixed Exchange Rate (FER) & 2.47 \\
FER with BMP & 1.03 \\
FER with MCC & 1.70 \\
Optimal Taylor Rule (OTR) & -0.05 \\
OTR with Optimal BMP & 0.28 \\
FER with Optimal BMP & \\
\hline Notes: $\Upsilon$ is a measure of welfare loss in units of steady-state consumption. It rep- \\
resents the fraction of consumption (in \%) required to equate welfare under any \\
given policy rule to the one under the optimal simple rule (see equation (23)), in the \\
face of a 1 percent financial shock. Welfare is calculated as conditional to the initial \\
deterministic steady state in each case.
\end{tabular}


Table 5. Optimized Parameters of the Policy Rules

\begin{tabular}{|l|c|c|c|}
\hline & \multicolumn{2}{|c|}{ Taylor Rule } & $\begin{array}{c}\text { Macroprudential } \\
\text { Policy }\end{array}$ \\
\cline { 2 - 4 } & $\begin{array}{c}\text { Inflation } \\
\text { Rate } \\
\left(\boldsymbol{\epsilon}_{\boldsymbol{\pi}}\right)\end{array}$ & $\begin{array}{c}\text { Output } \\
\text { Gap } \\
\left(\boldsymbol{\epsilon}_{y}\right)\end{array}$ & $\begin{array}{c}\text { Credit } \\
\text { Growth } \\
\mathbf{( \Psi )}\end{array}$ \\
\hline $\begin{array}{l}\text { Optimal Taylor Rule (OTR) } \\
\text { OTR with Optimal BMP }\end{array}$ & 1.1 & 0 & - \\
FER with Optimal BMP & 2.7 & 0.25 & 1.4 \\
\hline $\begin{array}{l}\text { Notes: We calculate the optimized parameters by searching numerically in the grid } \\
\text { of parameters }\left\{\epsilon_{\pi}, \epsilon_{y}, \Psi\right\} \text { that optimize welfare } \\
\text { financial shock in response to the 1 percent } \\
\text { deterministic steady state in each case. }\end{array}$ \\
\hline
\end{tabular}

reaction function, and more than 1 percent of steady-state consumption under the fixed exchange rate regime. More interestingly, even when the coefficients of the Taylor rule are optimized to minimize the welfare loss after the shock, the optimized coefficient for the macroprudential instrument is not zero (1.4); i.e., there is room for macroprudential policies to play. The presence of the macroprudential instrument calls for a more aggressive monetary policy response to inflation (2.7 as opposed to 1.1) and output ( 0.25 as opposed to 0$)$. The welfare gains obtained from macroprudential capital controls, however, are negligible, confirming results obtained in the previous section.

Our analysis is related to other recent studies exploring the benefits of introducing macroprudential measures. Bianchi and Mendoza (2010) and Bianchi (2011) compute welfare gains associated with macroprudential policy interventions to correct a (negative) credit externality. In its simple form (as in this paper), a macroprudential policy intervention provides welfare gains by about 0.02 percent of permanent consumption (calculated for the United States) in Bianchi and Mendoza (2010) and 0.08 percent of permanent consumption (calculated for emerging-market economies) in Bianchi (2011). These are quite close to our result; we find that the welfare gain with broad macroprudential measures under the optimal monetary policy rule is about 0.05 percent of steady-state 
consumption. $^{26}$ Still, welfare gains with macroprudential measures are small in our analysis, as well as in others. Note, however, that we restrict the policymakers to follow simple policy rules in implementing macroprudential policy, similar to the interest rate policy employed in the New Keynesian literature. Fully optimal, statecontingent macroprudential policies are not easy to implement in practice, but they could result in higher welfare gains. Indeed, Bianchi and Mendoza (2010) argue that welfare gains with simple macroprudential policies are about 30 percent of those attained under optimal policy intervention. Nevertheless, Bianchi (2011) finds that simple forms of macroprudential policies such as fixed taxes on debt achieve welfare gains that are very close to the fully optimal policies. $^{27}$

In a closer framework to ours, but using a closed-economy setup, Angeloni and Faia (2009), Kannan, Rabanal, and Scott (2009), and Angeloni, Faia, and Lo Duca (2010) also show that the use of macroprudential policies improves economic stability. Angeloni and Faia (2009) find that introducing countercyclical capital requirements increases welfare by about 0.1 percent of steady-state consumption under a Taylor-type rule, which is smaller than the welfare gains in our analysis (0.76 - the difference between the first and the second row in table 4). The differences between the two results could be brought by the smaller responsiveness of the macroprudential instrument in their paper (0.1) than in our paper $(0.5)$, as well as differences in the model setups. Using ad hoc specifications of a welfare function (composed of variances of macroeconomic and financial variables), Kannan, Rabanal, and Scott (2009) and Angeloni, Faia, and Lo Duca (2010) also find that macroprudential policies are useful even under the optimized monetary policy rule. However, model structures and, in particular, welfare measurements in those papers are at variance with ours, as is the size of the optimized monetary and macroprudential responses.

\footnotetext{
${ }^{26}$ Monetary policy and hence its interactions with macroprudential policies are absent in Bianchi and Mendoza (2010) and Bianchi (2011). Therefore, we focus on the optimal monetary policy rule with and without macroprudential measures when we do the comparison.

${ }^{27}$ Benigno et al. (2012) find that policy intervention should be geared toward inducing more rather than less borrowing, particularly in crisis times. In their framework, any form of tax on debt (state contingent or not) reduces welfare.
} 
The analysis yields another important result - the exchange rate regime matters for the desirability of using macroprudential policies. The optimized coefficient for the broad macroprudential policy instrument is higher under the fixed exchange rate regime (2.7) than under the Taylor-rule type of monetary policy regime (1.4). The intuition for why is as follows. Under the Taylor rule, the interest rate rises in response to rising inflation and output. The rise in the interest rate decreases consumption and investment but also limits the increase credit growth. Under a fixed exchange rate regime, the impact of the shock on the economy is more dramatic given the absence of an independent interest rate tool, which puts more of the burden on macroprudential policies to provide macroeconomic and financial stability. ${ }^{28}$

Focusing exclusively on capital controls, Schmitt-Grohe and Uribe (2012) calculate that welfare gains associated with macroprudential policies are about 2 to 5 percent of steady-state consumption, close to our result of 2.2 percent (the difference between the fourth and the last row in table 4). Similarly, Farhi and Werning (2012) conjecture that intervention measures lean less against the wind when the exchange rate is flexible than when the exchange rate is fixed. ${ }^{29}$

\section{How Do Macroprudential Measures Perform Following a Productivity Shock?}

We have analyzed so far the role of macroprudential measures in macroeconomic policymaking under a financial shock, an exogenous change in investors' perception about the entrepreneurs' productivity. Under that scenario, the responses of monetary policy and macroprudential measures are aligned (both are contractionary).

\footnotetext{
${ }^{28}$ Country experiences seem to support this result. For example, Lim et al. (2011) find that economies with fixed or managed exchange rate regimes tend to use macroprudential tools more frequently.

${ }^{29}$ Both Schmitt-Grohe and Uribe (2012) and Farhi and Werning (2012) allow only foreign borrowing in their model. Hence, capital controls in these papers are not selective in nature, and by construction there is no difference between broad macroprudential measures and macroprudential capital controls in effective terms. Therefore, our welfare results with broad macroprudential measures under the fixed exchange rate regime are comparable with theirs.
} 
However, there could be other shocks that generate a trade-off between macroeconomic and financial stability objectives. For example, under a productivity shock, entrepreneurs increase their borrowings, and investment and asset prices rise as in the previous scenario. On the one hand, inflation declines, and the monetary authority responds by decreasing the interest rate under the Taylor rule (figure 5). On the other hand, macroprudential measures call for a higher lending rate in order to dampen the expanding leverage in the economy.

Overall, simulations show that stabilization benefits of introducing macroprudential measures decline under a productivity shock. When broad macroprudential policy is implemented, the output response changes only marginally, while the response of inflation is even higher and the policy rate is lowered by almost two times more relative to the case without macroprudential policies. In fact, under a productivity shock, macroprudential measures are not welfare improving (table 6). Not surprisingly, the coefficient of the macroprudential instrument that maximizes welfare turns out to be zero.

Kannan, Rabanal, and Scott (2009) and Angeloni, Faia, and Lo Duca (2010) also find that the desirability of macroprudential measures is sizably reduced under a productivity shock. Despite the fact that their welfare measurements and model setups are different than ours, both of these papers find that the optimal response through a macroprudential instrument is much smaller under a productivity shock relative to the case under a financial shock.

\section{Conclusions}

This paper has developed an open-economy DSGE model to investigate whether there is a potential role for macroprudential policies in helping monetary policy stabilize the economy. The simulations suggest that macroprudential tools could be useful at times in helping to achieve twin objectives of macroeconomic and financial stability. In particular, broad macroprudential measures are shown to improve welfare in the case of a surge in capital inflows triggered by a financial optimism shock. Even under the optimal monetary policy rule, broad macroprudential measures are still beneficial. Macroprudential measures that discriminate against 
Figure 5. A Positive Productivity Shock: Taylor Rule and Broad Macroprudential Policy (percent deviations from the steady state)
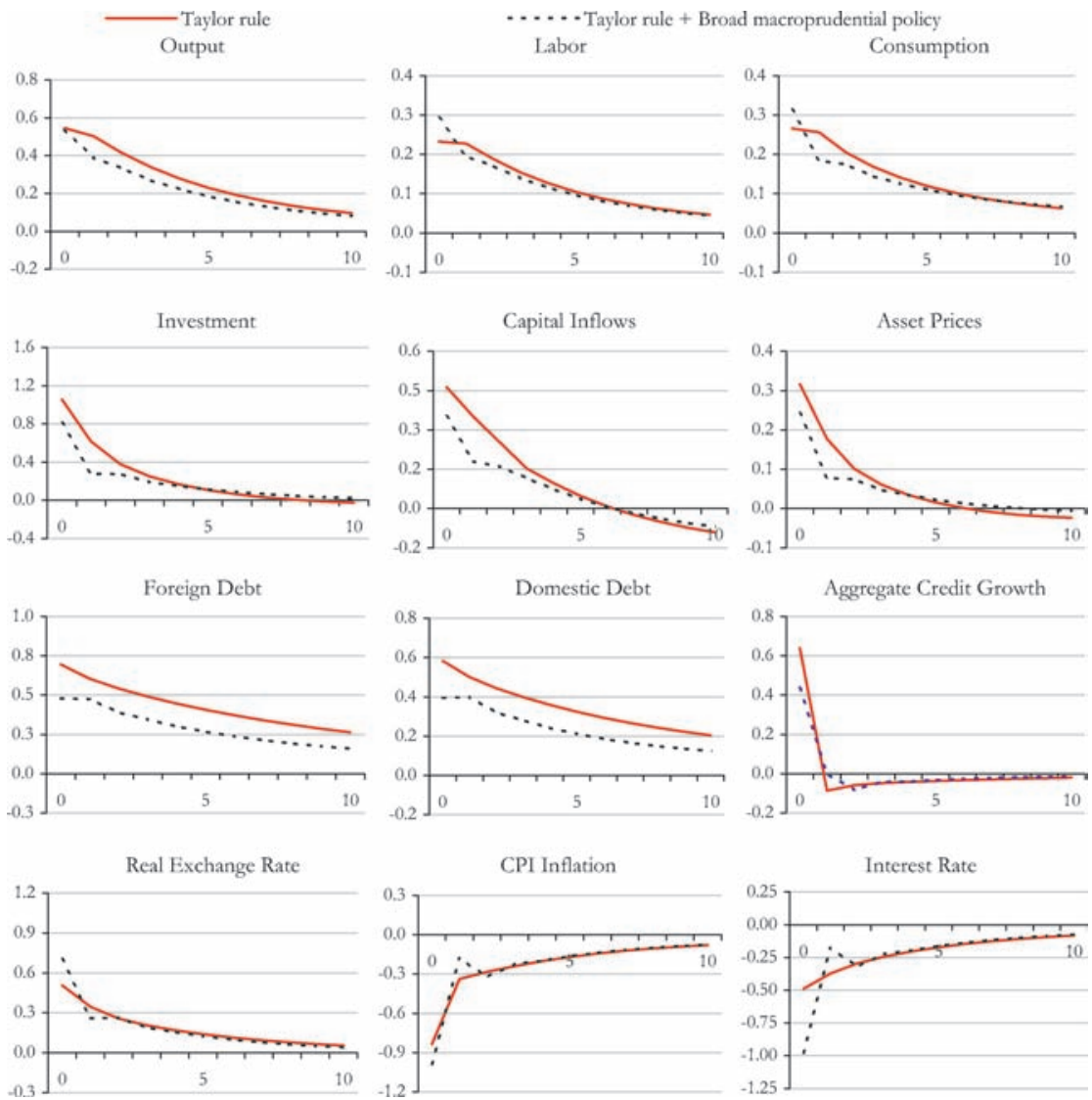

Notes: The figures show the impact of a 1 percent positive productivity shock. The variables are presented as log-deviations from the steady state (except for interest rate), multiplied by 100 to have an interpretation of percentage deviations.

foreign liabilities (macroprudential capital controls), however, are less effective than broader macroprudential measures in mitigating the impact of the shock. In that approach, although capital inflows are smaller in size, domestic financial imbalances could still build up. 


\section{Table 6. Welfare Results under a Productivity Shock, in Percent of Steady-State Consumption}

\begin{tabular}{|l|c|}
\hline & $\Upsilon$ \\
\hline Taylor Rule (TR) & 2.17 \\
TR with Broad Macroprudential Policy (BMP) & 2.36 \\
Optimal Taylor Rule (OTR) & \\
\hline $\begin{array}{l}\text { Notes: } \Upsilon \text { is a measure of welfare loss in units of steady-state consumption. It repre- } \\
\text { sents the fraction of consumption (in \%) required to equate welfare under any given } \\
\text { policy rule to the one under the optimal simple rule (see equation (23)), in the face } \\
\text { of a } 1 \text { percent productivity shock. Welfare is calculated as conditional to the initial } \\
\text { deterministic steady state in each case. }\end{array}$ \\
\hline
\end{tabular}

The exchange rate regime matters for the desirability of using the macroprudential policy instrument as a separate policy tool. Broad macroprudential policies are useful both under fixed and flexible exchange rate regimes. However, under the fixed exchange rate regime, the optimal response through the macroprudential tool is bigger, as the absence of an independent interest rate tool puts more of the burden on macroprudential policies to address macroeconomic and financial instability.

Our analysis supports the use of broad macroprudential policies in macroeconomic policymaking in the face of a financial shock. Whether these macroprudential measures could also help monetary policy in stabilizing the economy under other types of shocks, however, is not obvious. As an example, we consider a productivity shock that creates a trade-off between macroeconomic stability and financial stability objectives. In our simulations, macroprudential policy is not welfare improving under the productivity shock. This has implications for the implementation of the macroprudential policies. In particular, policymakers should be cautious in reacting rigidly to financial market developments. Rather, some form of flexibility to deal appropriately with various types of shocks could be more desirable.

One limitation of the paper is that the solution method relies on perpetuations methods - linearization in particular. In order to keep the model sufficiently flexible to handle rich and realistic features, we solve the second-order (linear) system and produce locally accurate 
approximations to the dynamics of the model, without considering global (non-linear) approximations. We acknowledge, however, that our framework abstracts from non-linearities that seem to play an important role in financial crises, and interactions between the ex post policy interventions in financial markets and the ex ante buildup of risk; and our welfare analysis is limited to the deterministic steady state as opposed to the stationary distribution.

Although the way macroprudential measures are modeled in this paper is intuitive, it does not allow us to focus on a particular type of these measures, such as reserve requirements or capital requirements. To address this issue, we are extending the model with a fully optimized banking sector, which would also make it possible to derive the regulation premium from microfoundations.

\section{Appendix 1. Model Equations: Domestic Economy}

\section{Households}

Demand functions for home and foreign goods are derived from the household's minimization of expenditure, conditional on total composite demand, and are as follows:

$$
\begin{gathered}
C_{H, t}=(1-\alpha)\left(\frac{P_{H, t}}{P_{t}}\right)^{-\gamma} C_{t}, \\
C_{M, t}=\alpha\left(\frac{P_{M, t}}{P_{t}}\right)^{-\gamma} C_{t},
\end{gathered}
$$

and the corresponding price index is given by

$$
P_{t}=\left[(1-\alpha) P_{H, t}^{1-\gamma}+\alpha P_{M, t}^{1-\gamma}\right]^{1 /(1-\gamma)},
$$

where $P_{H, t}$ and $P_{M, t}$ represent the prices for domestic and imported goods and $P_{t}$ denotes the consumer price index (CPI).

The representative household chooses the paths for $\left\{C_{t}, H_{t}\right.$, $\left.D_{t+1}^{D}, D_{t+1}^{H}\right\}_{t=0}^{\infty}$ in order to maximize its expected lifetime utility in equation (1) subject to the budget constraint in equation (3). The first-order conditions for this optimization problem are given by 


$$
\begin{aligned}
& \chi H_{t}^{\varphi}=W_{t} \\
& \left(C_{t}-\frac{\chi}{1+\varphi} H_{t}^{1+\varphi}\right)^{-\sigma} \\
& =\beta\left(1+i_{t}\right) E_{t}\left[\left(C_{t+1}-\frac{\chi}{1+\varphi} H_{t+1}^{1+\varphi}\right)^{-\sigma} \frac{P_{t}}{P_{t+1}}\right] \\
& \left(C_{t}-\frac{\chi}{1+\varphi} H_{t}^{1+\varphi}\right)^{-\sigma} \\
& =\beta\left(1+i_{t}^{*}\right) \Psi_{D, t} E_{t}\left[\left(C_{t+1}-\frac{\chi}{1+\varphi} H_{t+1}^{1+\varphi}\right)^{-\sigma} \frac{P_{t}}{P_{t+1}} \frac{S_{t+1}}{S_{t}}\right]
\end{aligned}
$$

In the absence of the premium paid on foreign borrowing $\left(\Psi_{D, t}\right)$, the last two equations would yield the standard uncovered interest rate parity condition.

\section{Production Firms}

Assuming that the price of each input is taken as given, the production firms minimize their costs subject to (4). Omitting the firmspecific indices for notational simplicity, cost-minimizing behavior implies the following first-order conditions:

$$
\begin{aligned}
W_{t} & =\frac{(1-\eta)(1-\Omega) Y_{t} M C_{t}}{N_{t}}, \\
W_{t}^{E} & =(1-\eta) \Omega Y_{t} M C_{t}, \\
R_{t} & =\frac{\eta Y_{t} M C_{t}}{K_{t}},
\end{aligned}
$$

where $W_{t}^{E}$ is the entrepreneurial wage rate, $R_{t}$ is the rental rate of capital, and $M C_{t}$ is the (nominal) marginal cost given by $M C_{t}=$ $\frac{R_{t}^{\eta} W_{t}^{1-\eta}}{A_{t} \eta^{\eta}(1-\eta)^{1-\eta}}$.

Let $Y_{X, t}$ denote the foreign aggregate export demand for domestic goods which is determined in the foreign economy (see appendix 2). Since the profit-maximization condition is symmetric among firms, the optimal price-setting equations can be written in aggregate terms. Using equations (5) and (6) in the text, we derive 


$$
\begin{aligned}
P_{H, t}= & \frac{\lambda}{\lambda-1} M C_{t}-\frac{\Psi_{H}}{\lambda-1} \frac{P_{t}}{Y_{H, t}} \frac{P_{H, t}}{P_{H, t-1}}\left(\frac{P_{H, t}}{P_{H, t-1}}-1\right) \\
& +\frac{\Psi_{H}}{\lambda-1} E_{t}\left[\Theta_{t} \frac{P_{t+1}}{Y_{H, t}} \frac{P_{H, t+1}}{P_{H, t}}\left(\frac{P_{H, t+1}}{P_{H, t}}-1\right)\right], \\
S_{t} P_{X, t}= & \frac{\lambda}{\lambda-1} M C_{t}-\frac{\Psi_{X}}{\lambda-1} \frac{P_{t}}{Y_{X, t}} \frac{P_{X, t}}{P_{X, t-1}}\left(\frac{P_{X, t}}{P_{X, t-1}}-1\right) \\
& +\frac{\Psi_{X}}{\lambda-1} E_{t}\left[\Theta_{t} \frac{P_{t+1}}{Y_{X, t}} \frac{P_{X, t+1}}{P_{X, t}}\left(\frac{P_{X, t+1}}{P_{X, t}}-1\right)\right],
\end{aligned}
$$

where $\Theta_{t}=\beta \frac{\left(C_{t+1}-\frac{\chi}{1+\varphi} H_{t+1}^{1+\varphi}\right)^{-\sigma}}{\left(C_{t}-\frac{\chi}{1+\varphi} H_{t}^{1+\varphi}\right)^{-\sigma}} \frac{P_{t}}{P_{t+1}}$.

\section{Importing Firms}

Let $Y_{M, t}$ denote the aggregate import demand of the domestic economy. Similar to production firms, the profit-maximization condition for importing firms gives the price index for the imported goods:

$$
\begin{aligned}
P_{M, t}= & \frac{\lambda}{\lambda-1} S_{t} P_{t}^{*}-\frac{\Psi_{M}}{\lambda-1} \frac{P_{t}}{Y_{M, t}} \frac{P_{M, t}}{P_{M, t-1}}\left(\frac{P_{M, t}}{P_{M, t-1}}-1\right) \\
& +\frac{\Psi_{M}}{\lambda-1} E_{t}\left[\Theta_{t} \frac{P_{t+1}}{Y_{M, t}} \frac{P_{M, t+1}}{P_{M, t}}\left(\frac{P_{M, t+1}}{P_{M, t}}-1\right)\right] .
\end{aligned}
$$

\section{Unfinished-Capital-Producing Firms}

Given equation (7), the cost-minimization problem of the unfinishedcapital-producing firms yields

$$
I_{H, t}=(1-\alpha)\left(\frac{P_{H, t}}{P_{t}}\right)^{-\gamma} I_{t}
$$

and

$$
I_{M, t}=\alpha\left(\frac{P_{M, t}}{P_{t}}\right)^{-\gamma} I_{t} .
$$

Equations (36) and (37), together with the equation defining the dynamics of stock of capital, equation (8), and price of capital, equation (9), describe unfinished-capital-producing firms in the model. 


\section{Entrepreneurs}

We omit entrepreneur index $k$ for notational simplicity. The contract between the lender and the entrepreneur characterizes a default threshold, $\bar{\omega}_{t+1}^{v}$, such that if $\omega_{t+1}^{v} \geq \bar{\omega}_{t+1}^{v}$, the lender receives a fixed return in the form of a contracted interest on the debt. If $\omega_{t+1}^{v}<\bar{\omega}_{t+1}^{v}$, then the borrower defaults; the lender audits by paying the monitoring cost and keeps what it finds. Therefore, we can define the expected return to entrepreneurs $v=F, D$ and lenders, respectively, as follows (ignoring entrepreneur specific):

$$
\begin{aligned}
& E_{t}\left[R_{t+1}^{K} Q_{t} K_{t+1}^{v}\left(\int_{\bar{\omega}_{t+1}^{v}}^{\infty} \omega^{v} f\left(\omega^{v}\right) d \omega^{v}-\bar{\omega}_{t+1}^{v} \int_{\bar{\omega}_{t+1}}^{\infty} f\left(\omega^{v}\right) d \omega^{v}\right)\right] \\
& =E_{t}\left[R_{t+1}^{K} Q_{t} K_{t+1}^{v} z^{v}\left(\bar{\omega}_{t+1}^{v}\right)\right] \\
& E_{t}\left[R _ { t + 1 } ^ { K } Q _ { t } K _ { t + 1 } ^ { v } \left(\bar{\omega}_{t+1}^{v *} \int_{\bar{\omega}_{t+1}^{v}}^{\infty} f\left(\omega^{v *}\right) d \omega^{v *}\right.\right. \\
& \left.\left.\quad+(1-\mu) \int_{0}^{\bar{\omega}_{t+1}^{v}} \omega_{t+1}^{v *} f\left(\omega^{v *}\right) d \omega^{v *}\right)\right] \\
& =E_{t}\left[R_{t+1}^{K} Q_{t} K_{t+1}^{v} g^{v}\left(\bar{\omega}_{t+1}^{v} ; \varrho_{t}^{v}\right)\right],
\end{aligned}
$$

where $R_{t}^{K}$ denotes the ex post realization of return to capital and is the same regardless of the source of the financing due to arbitrage. $z^{v}(\bar{\omega})$ is the borrowers' share of the total return. We use the definition of the lender's perception of productivity shock $\omega_{t+1}^{v *}$ in equation (39), where $g^{v}\left(\bar{\omega}^{v} ; \varrho^{v}\right)$ represents the lender's share of the total return, itself a function of both the idiosyncratic shock and the perception factor.

For domestic and foreign lenders, the opportunity cost of lending to the entrepreneur is the domestic interest rate $\left(1+i_{t}\right)$ and $\left(1+i_{t}^{*}\right)$. Thus the loan contract must satisfy the following for the lenders to be willing to participate in it:

$$
\begin{aligned}
E_{t}\left[\frac{R_{t+1}^{K} Q_{t} K_{t+1}^{F}}{S_{t+1}} g^{F}\left(\bar{\omega}_{t+1}^{F} ; \varrho_{t}^{F}\right)\right] & =\left(1+i_{t}^{*}\right) D_{t+1}^{F}, \\
E_{t}\left[R_{t+1}^{K} Q_{t} K_{t+1}^{D} g^{D}\left(\bar{\omega}_{t+1}^{D} ; \varrho_{t}^{D}\right)\right] & =\left(1+i_{t}\right) D_{t+1}^{D} .
\end{aligned}
$$


The contracting problem identifies the capital demand of entrepreneurs, $K_{t+1}^{v}$, and a cut-off value, $\bar{\omega}_{t+1}^{v}$, such that the entrepreneurs will maximize (38) subject to (40) and (41). The first-order conditions yield (12)-(15) in the text.

Given that the borrower's and the lender's share of total return should add up to $z^{v}\left(\bar{\omega}_{t}^{v}\right)+g^{v}\left(\bar{\omega}_{t}^{v}, \varrho_{t}^{v}\right)=1-\nu_{t}^{v}$ (where $\nu_{t}^{v}$ is the cost of monitoring, a deadweight loss associated with financial frictions) and by using the participation constraints (40) and (41), we can rewrite foreign and domestic borrowing entrepreneurs' net worth as

$$
\begin{aligned}
& P_{t} N W_{t}^{F}=\vartheta\left[R_{t}^{K} Q_{t-1} K_{t}^{F}\left(1-\nu_{t}^{F}\right)-\left(1+i_{t-1}^{*}\right) S_{t} D_{t}^{F}\right]+W_{t}^{F E}, \\
& P_{t} N W_{t}^{D}=\vartheta\left[R_{t}^{K} Q_{t-1} K_{t}^{D}\left(1-\nu_{t}^{D}\right)-\left(1+i_{t-1}\right) D_{t}^{D}\right]+W_{t}^{D E} .
\end{aligned}
$$

The entrepreneurs leaving the scene at time $t$ consume their return on capital. The consumption of the exiting entrepreneurs, $C_{t}^{v E}$, can then be written as

$$
\begin{aligned}
& P_{t} C_{t}^{F E}=(1-\vartheta)\left[R_{t}^{K} Q_{t-1} K_{t}^{F}\left(1-\nu_{t}^{F}\right)-\left(1+i_{t-1}^{*}\right) S_{t} D_{t}^{F}\right] \\
& P_{t} C_{t}^{D E}=(1-\vartheta)\left[R_{t}^{K} Q_{t-1} K_{t}^{D}\left(1-\nu_{t}^{D}\right)-\left(1+i_{t-1}\right) D_{t}^{D}\right] .
\end{aligned}
$$

It is assumed that the entrepreneurs consume an identical mix of domestic and foreign goods in their consumption basket with the households given in equation (2). Therefore the entrepreneurs' demand functions for domestic and imported consumption goods are given by

$$
\begin{aligned}
C_{H, t}^{v E} & =(1-\alpha)\left(\frac{P_{H, t}}{P_{t}}\right)^{-\gamma} C_{t}^{v E}, \\
C_{M, t}^{v E} & =\alpha\left(\frac{P_{M, t}}{P_{t}}\right)^{-\gamma} C_{t}^{v E}
\end{aligned}
$$

To define $z^{v}(\bar{\omega})$ and $g^{v}\left(\bar{\omega}^{v} ; \varrho^{v}\right)$, we use the relationship between the functions $\operatorname{erf}($.$) and \operatorname{erf} c($.$) and the cumulative distribution function$ of a standard normal distribution $\Theta($.$) :$

$$
\begin{aligned}
\operatorname{erf}(x) & =2 \Theta(x \sqrt{2})-1, \\
\operatorname{erf} c(x) & =2(1-\Theta(x \sqrt{2})) .
\end{aligned}
$$


Using (48) and two artificial variables $z_{1 t}^{v}=\frac{\ln \omega_{t}^{v}+0.5 \sigma_{\omega}^{v 2}}{\sigma_{\omega}^{v}}$ and $z_{2 t}^{v}=\frac{\ln \left(\frac{\omega_{t}^{v}}{\varrho_{t}}\right)+0.5 \sigma_{\omega}^{v 2}}{\sigma_{\omega}^{v}}$, we redefine $z^{v}(),. g^{v}(),. z^{v \prime}($.$) , and g^{v \prime}($.$) :$

$$
\begin{gathered}
z^{v}\left(\bar{\omega}_{t}^{v}\right)=1-\Theta\left(z_{1 t}^{v}-\sigma_{\omega}^{v}\right)-\bar{\omega}_{t}^{v}\left(1-\Theta\left(z_{1 t}^{v}\right)\right), \\
g^{v}\left(\bar{\omega}_{t}^{v} ; \varrho_{t}\right)=\varrho_{t}\left[\frac{\bar{\omega}_{t}^{v}}{\varrho_{t}}\left(1-\Theta\left(z_{2 t}^{v}\right)\right)+(1-\mu) \Theta\left(z_{2 t}^{v}-\sigma_{\omega}^{v}\right)\right], \\
z^{v \prime}\left(\bar{\omega}_{t}^{v}\right)=-\left(1-\Theta\left(z_{1 t}^{v}\right)\right), \\
g^{v \prime}\left(\bar{\omega}_{t}^{v} ; \varrho_{t}\right)=\varrho_{t}\left[1-\Theta\left(z_{2 t}^{v}\right)-\frac{\mu}{\sqrt{2 \pi} \sigma_{\omega}^{v}} \exp \left(-\frac{z_{2 t}^{v 2}}{2}\right)\right] .
\end{gathered}
$$

Equations (40)-(52), together with (12)-(17), form the entrepreneurs block of the model.

\section{Financial Intermediaries and Macroprudential Policy}

Model equations for financial intermediaries and macroprudential policies are given in (18)-(20).

\section{Monetary Policy}

In the baseline case, we assume that monetary policy reaction function follows a Taylor-type rule with interest rate smoothing as given in (21).

\section{General Equilibrium and Balance-of-Payments Dynamics}

Market clearing in the final good sector requires that total domestic output be equal to domestic consumption, domestic investment, and exports to the rest of the world. Frictions such as adjustment and monitoring costs are included in the output, given that they are expressed in terms of the final composite good. Thus the overall resource constraint faced by the domestic economy can be written as

$$
Y_{t}=Y_{H, t}+Y_{X, t}
$$


where

$$
\begin{aligned}
Y_{H, t}= & C_{H, t}+C_{H, t}^{E}+I_{H, t} \\
& +(1-\alpha)\left(\frac{P_{H, t}}{P_{t}}\right)^{-\gamma}\left[\sum_{i=H, X} \frac{\Psi_{i}}{2}\left(\frac{P_{i, t}}{P_{i, t-1}}-1\right)^{2}\right. \\
& \left.+\frac{\Psi_{M}}{2}\left(\frac{P_{M, t}}{P_{M, t-1}}-1\right)^{2}+\sum_{j=F, D} \nu_{t}^{j} \frac{R_{t}^{K}}{P_{t}} Q_{t-1} K_{t}^{j}\right] .
\end{aligned}
$$

The import demand of the domestic economy (which is the export of the foreign economy) $Y_{X, t}^{*}$, can be expressed as follows:

$$
\begin{aligned}
Y_{X, t}^{*}= & C_{M, t}+C_{M, t}^{E}+I_{M, t}+\alpha\left(\frac{P_{M, t}}{P_{t}}\right)^{-\gamma}\left[\sum_{i=H, X} \frac{\Psi_{i}}{2}\left(\frac{P_{i, t}}{P_{i, t-1}}-1\right)^{2}\right. \\
& \left.+\frac{\Psi_{M}}{2}\left(\frac{P_{M, t}}{P_{M, t-1}}-1\right)^{2}+\sum_{j=F, D} \nu_{t}^{j} \frac{R_{t}^{K}}{P_{t}} Q_{t-1} K_{t}^{j}\right]
\end{aligned}
$$

where $C_{M, t}$ and $C_{M, t}^{E}$ are demand for imports by households and entrepreneurs, respectively, and $I_{M, t}$ is the domestic economy's import demand for investment goods.

Substituting (48) and the profits of both the final-goodproducing and the importing firms into the budget constraints of the households and the entrepreneurs yields the following balanceof-payments condition after aggregation:

$$
\begin{aligned}
S_{t} P_{X, t} Y_{X, t}-S_{t} P_{t}^{*} Y_{X, t}^{*}= & S_{t}\left(1+i_{t-1}^{*}\right)\left(D_{t}^{H} \Psi_{D, t-1}+D_{t}^{F}\right) \\
& -S_{t}\left(D_{t+1}^{H}+D_{t+1}^{F}\right)
\end{aligned}
$$

where the first and second terms on the left are exports and imports, respectively. On the right is simply the change in the net foreign asset position, aggregated over households and entrepreneurs. 


\section{Appendix 2. Model Equations: The Rest of the World}

Apart from being asymmetric in size, the domestic economy and the rest of the world share the same preferences, technology, and market structure for consumption and capital goods. Therefore, we only present equations here for the rest-of-the-world part of the model, and give only brief explanation when necessary.

Households

$$
\begin{gathered}
C_{H, t}^{*}=\left(1-\alpha^{*}\right)\left(\frac{P_{H, t}^{*}}{P_{t}^{*}}\right)^{-\gamma^{*}} C_{t}^{*}, \\
C_{M, t}^{*}=\alpha^{*}\left(\frac{P_{M, t}^{*}}{P_{t}^{*}}\right)^{-\gamma^{*}} C_{t}^{*}, \\
P_{t}^{*}=\left[\left(1-\alpha^{*}\right) P_{H, t}^{* 1-\gamma^{*}}+\alpha^{*} P_{M, t}^{* 1-\gamma^{*}}\right]^{1 /\left(1-\gamma^{*}\right)}, \\
\chi H_{t}^{* \varphi}=W_{t}^{*}, \\
\left(C_{t}^{*}-\frac{\chi}{1+\varphi} H_{t}^{* 1+\varphi}\right)^{-\sigma} \\
=\beta\left(1+i_{t}^{*}\right) E_{t}\left[\left(C_{t+1}^{*}-\frac{\chi}{1+\varphi} H_{t+1}^{* 1+\varphi}\right)^{-\sigma} \frac{P_{t}^{*}}{P_{t+1}^{*}}\right] .
\end{gathered}
$$

Production Firms

$$
\begin{gathered}
W_{t}^{*}=\frac{(1-\eta)(1-\Omega) Y_{t}^{*} M C_{t}^{*}}{N_{t}^{*}}, \\
W_{t}^{* E}=(1-\eta) \Omega Y_{t}^{*} M C_{t}^{*}, \\
R_{t}^{*}=\frac{\eta Y_{t}^{*} M C_{t}^{*}}{K_{t}^{*}}, \\
P_{H, t}^{*}=\frac{\lambda}{\lambda-1} M C_{t}^{*}-\frac{\Psi_{H}}{\lambda-1} \frac{P_{t}^{*}}{Y_{H, t}^{*}} \frac{P_{H, t}^{*}}{P_{H, t-1}^{*}}\left(\frac{P_{H, t}^{*}}{P_{H, t-1}^{*}}-1\right) \\
+\frac{\Psi_{H}}{\lambda-1} E_{t}\left[\Theta_{t}^{*} \frac{P_{t+1}^{*}}{Y_{H, t}^{*}} \frac{P_{H, t+1}^{*}}{P_{H, t}^{*}}\left(\frac{P_{H, t+1}^{*}}{P_{H, t}^{*}}-1\right)\right],
\end{gathered}
$$




$$
\begin{aligned}
S_{t}^{*} P_{X, t}^{*}= & \frac{\lambda}{\lambda-1} M C_{t}^{*}-\frac{\Psi_{X}}{\lambda-1} \frac{P_{t}^{*}}{Y_{X, t}^{*}} \frac{P_{X, t}^{*}}{P_{X, t-1}^{*}}\left(\frac{P_{X, t}^{*}}{P_{X, t-1}^{*}}-1\right) \\
& +\frac{\Psi_{X}}{\lambda-1} E_{t}\left[\Theta_{t}^{*} \frac{P_{t+1}^{*}}{Y_{X, t}^{*}} \frac{P_{X, t+1}^{*}}{P_{X, t}^{*}}\left(\frac{P_{X, t+1}^{*}}{P_{X, t}^{*}}-1\right)\right],
\end{aligned}
$$

where $\Theta_{t}^{*}=\beta \frac{\left(C_{t+1}^{*}-\frac{\chi}{1+\varphi} H_{t+1}^{* 1+\varphi}\right)^{-\sigma}}{\left(C_{t}^{*}-\frac{\chi}{1+\varphi} H_{t}^{* 1+\varphi}\right)^{-\sigma}} \frac{P_{t}^{*}}{P_{t+1}^{*}}$.

Importing Firms

$$
\begin{aligned}
P_{M, t}= & \frac{\lambda}{\lambda-1} S_{t}^{*} P_{t}^{*}-\frac{\Psi_{M}}{\lambda-1} \frac{P_{t}}{Y_{M, t}} \frac{P_{M, t}}{P_{M, t-1}}\left(\frac{P_{M, t}}{P_{M, t-1}}-1\right) \\
& +\frac{\Psi_{M}}{\lambda-1} E_{t}\left[\Theta_{t} \frac{P_{t+1}}{Y_{M, t}} \frac{P_{M, t+1}}{P_{M, t}}\left(\frac{P_{M, t+1}}{P_{M, t}}-1\right)\right] .
\end{aligned}
$$

Unfinished-Capital-Producing Firms

$$
\begin{gathered}
I_{H, t}^{*}=\left(1-\alpha^{*}\right)\left(\frac{P_{H, t}^{*}}{P_{t}^{*}}\right)^{-\gamma} I_{t}^{*}, \\
I_{M, t}^{*}=\alpha^{*}\left(\frac{P_{M, t}^{*}}{P_{t}^{*}}\right)^{-\gamma} I_{t}^{*}, \\
K_{t+1}^{*}=\left[\frac{I_{t}^{*}}{K_{t}^{*}}-\frac{\Psi_{I}}{2}\left(\frac{I_{t}^{*}}{K_{t}^{*}}-\delta\right)^{2}\right] K_{t}^{*}+(1-\delta) K_{t}^{*}, \\
\frac{Q_{t}^{*}}{P_{t}^{*}}=\left[1-\Psi_{I}\left(\frac{I_{t}^{*}}{K_{t}^{*}}-\delta\right)\right]^{-1} .
\end{gathered}
$$

Entrepreneurs

Entrepreneurs in the rest of the world only borrow domestically in their own currency.

$$
\begin{aligned}
& E_{t}\left[R_{t+1}^{K *} Q_{t}^{*} K_{t+1}^{*}\left(\int_{\bar{\omega}_{t+1}^{*}}^{\infty} \omega^{*} f\left(\omega^{*}\right) d \omega^{*}-\bar{\omega}_{t+1}^{*} \int_{\bar{\omega}^{*} t+1}^{\infty} f\left(\omega^{*}\right) d \omega^{*}\right)\right] \\
& \quad=E_{t}\left[R_{t+1}^{K *} Q_{t}^{*} K_{t+1}^{*} z^{*}\left(\bar{\omega}_{t+1}^{*}\right)\right],
\end{aligned}
$$




$$
\begin{aligned}
E_{t} & {\left[R _ { t + 1 } ^ { K * } Q _ { t } ^ { * } K _ { t + 1 } ^ { * } \left(\bar{\omega}_{t+1}^{*} \int_{\bar{\omega}_{t+1}^{*}}^{\infty} f\left(\omega^{*}\right) d \omega^{*}\right.\right.} \\
& \left.\left.+(1-\mu) \int_{0}^{\bar{\omega}_{t+1}^{*}} \omega_{t+1}^{*} f\left(\omega^{*}\right) d \omega^{*}\right)\right] \\
& =E_{t}\left[R_{t+1}^{K *} Q_{t} K_{t+1}^{*} g^{*}\left(\bar{\omega}_{t+1}^{*} ; \varrho_{t}^{*}\right)\right]
\end{aligned}
$$

$$
\begin{gathered}
E_{t}\left[R_{t+1}^{K *} Q_{t}^{*} K_{t+1}^{*} g^{*}\left(\bar{\omega}_{t+1}^{*} ; \varrho_{t}^{*}\right)\right]=\left(1+i_{t}^{*}\right) D_{t+1}^{*}, \\
P_{t}^{*} N W_{t}^{*}=\vartheta\left[R_{t}^{K *} Q_{t-1}^{*} K_{t}^{*}\left(1-\nu_{t}^{*}\right)-\left(1+i_{t-1}^{*}\right) D_{t}^{*}\right]+W_{t}^{E *} \\
P_{t}^{*} C_{t}^{E *}=(1-\vartheta)\left[R_{t}^{K *} Q_{t-1}^{*} K_{t}^{*}\left(1-\nu_{t}^{*}\right)-\left(1+i_{t-1}^{*}\right) D_{t}^{*}\right] \\
C_{H, t}^{E *}=\left(1-\alpha^{*}\right)\left(\frac{P_{H, t}^{*}}{P_{t}^{*}}\right)^{-\gamma} C_{t}^{E *} \\
C_{M, t}^{E *}=\alpha^{*}\left(\frac{P_{M, t}^{*}}{P_{t}^{*}}\right)^{-\gamma} C_{t}^{E *}, \\
E_{t}\left[R_{t+1}^{K *}\right]=E_{t}\left[\left(1+i_{t}^{*}\right)\left(1+\Phi_{t+1}^{*}\right)\right]
\end{gathered}
$$

$$
\begin{aligned}
& 1+\Phi_{t+1}^{*}=\left[\frac{z^{* \prime}\left(\bar{\omega}_{t+1}^{*}\right)}{g^{*}\left(\bar{\omega}_{t+1}^{*} ; \varrho_{t}^{*}\right) z^{* \prime}\left(\bar{\omega}_{t+1}^{*}\right)-z^{*}\left(\bar{\omega}_{t+1}^{*}\right) g^{*^{\prime}}\left(\bar{\omega}_{t+1}^{*} ; \varrho_{t}^{*}\right)}\right], \\
& z^{*}\left(\bar{\omega}_{t}^{*}\right)=1-\Theta\left(z_{1 t}^{*}-\sigma_{\omega}^{*}\right)-\bar{\omega}_{t}^{*}\left(1-\Theta\left(z_{1 t}^{*}\right)\right), \\
& g^{*}\left(\bar{\omega}_{t}^{*} ; \varrho_{t}^{*}\right)=\varrho_{t}^{*}\left[\frac{\bar{\omega}_{t}^{*}}{\varrho_{t}^{*}}\left(1-\Theta\left(z_{2 t}^{*}\right)\right)+(1-\mu) \Theta\left(z_{2 t}^{*}-\sigma_{\omega}^{*}\right)\right], \\
& z^{* \prime}\left(\bar{\omega}_{t}^{*}\right)=-\left(1-\Theta\left(z_{1 t}^{*}\right)\right), \\
& g^{* \prime}\left(\bar{\omega}_{t}^{*} ; \varrho_{t}^{*}\right)=\varrho_{t}^{*}\left[1-\Theta\left(z_{2 t}^{*}\right)-\frac{\mu}{\sqrt{2 \pi} \sigma_{\omega}^{*}} \exp \left(-\frac{z_{2 t}^{* 2}}{2}\right)\right. \text {, } \\
& E_{t}\left[R_{t+1}^{K *}\right]=E_{t}\left[\frac{R_{t+1}^{*}}{Q_{t}^{*}}+\frac{Q_{t+1}^{*}}{Q_{t}^{*}}\left\{(1-\delta)+\Psi_{I}\left(\frac{I_{t+1}^{*}}{K_{t+1}^{*}}-\delta\right) \frac{I_{t+1}^{*}}{K_{t+1}^{*}}\right.\right. \\
& \left.\left.-\frac{\Psi_{I}}{2}\left(\frac{I_{t+1}^{*}}{K_{t+1}^{*}}-\delta\right)^{2}\right\}\right]
\end{aligned}
$$


Financial Intermediaries and Macroprudential Policy

We assume that there is no macroprudential policy in the rest-ofthe-world block.

Monetary Policy

$$
1+i_{t}^{*}=\left[\left(1+i^{*}\right)\left(\pi_{t}^{*}\right)^{\epsilon_{\pi}^{*}}\left(Y_{t}^{*} / Y^{*}\right)^{\epsilon_{Y}^{*}}\right]^{\varpi^{*}}\left[1+i_{t-1}^{*}\right]^{1-\varpi^{*}} .
$$

General Equilibrium and Balance-of-Payments Dynamics

$$
\begin{gathered}
S_{t}^{*}=1 / S_{t}, \\
Y_{t}^{*}=Y_{H, t}^{*}+Y_{X, t}^{*},
\end{gathered}
$$

$Y_{H, t}^{*}=C_{H, t}^{*}+C_{H, t}^{E *}+I_{H, t}^{*}$

$$
\begin{aligned}
& +\left(1-\alpha^{*}\right)\left(\frac{P_{H, t}^{*}}{P_{t}^{*}}\right)^{-\gamma}\left[\sum_{i=H, X} \frac{\Psi_{i}}{2}\left(\frac{P_{i, t}^{*}}{P_{i, t-1}^{*}}-1\right)^{2}\right. \\
& \left.+\frac{\Psi_{M}}{2}\left(\frac{P_{M, t}^{*}}{P_{M, t-1}^{*}}-1\right)^{2}+\nu_{t}^{*} \frac{R_{t}^{K *}}{P_{t}^{*}} Q_{t-1}^{*} K_{t}^{*}\right], \\
Y_{X, t}= & C_{M, t}^{*}+C_{M, t}^{E *}+I_{M, t}^{*}+\alpha^{*}\left(\frac{P_{M, t}^{*}}{P_{t}^{*}}\right)^{-\gamma}\left[\sum_{i=H, X} \frac{\Psi_{i}}{2}\left(\frac{P_{i, t}^{*}}{P_{i, t-1}^{*}}-1\right)^{2}\right. \\
& \left.+\frac{\Psi_{M}}{2}\left(\frac{P_{M, t}^{*}}{P_{M, t-1}^{*}}-1\right)^{2}+\nu_{t}^{*} \frac{R_{t}^{K *}}{P_{t}^{*}} Q_{t-1}^{*} K_{t}^{*}\right] .
\end{aligned}
$$

\section{References}

Angeloni, I., and E. Faia. 2009. "A Tale of Two Policies: Prudential Regulation and Monetary Policy with Fragile Banks." Kiel Working Paper No. 1569.

Angeloni, I., E. Faia, and M. Lo Duca. 2010. "Monetary Policy and Risk Taking." Bruegel Working Paper. 
Bank for International Settlements. 2010. "Group of Central Bank Governors and Heads of Supervision Reinforces Basel Committee Reform Package." BIS Press Release, January 11.

Bank of England. 2009. "The Role of Macroprudential Policy." Discussion Paper (November).

Benigno, G., C. Huigang, O. Cristopher, R. Alessandro, and E. Young. 2012. "Financial Crises and Macro-Prudential Policies." Forthcoming in Journal of International Economics.

Bernanke, B. S., M. Gertler, and S. Gilchrist. 1999. "The Financial Accelerator in a Quantitative Business Cycle Framework." In Handbook of Macroeconomics, ed. J. B. Taylor and M. Woodford, Vol. 1C, 1341-93 (chapter 21). Amsterdam: North-Holland.

Bianchi, J. 2011. "Overborrowing and Systemic Externalities in the Business Cycle." American Economic Review 101 (7): 340026.

Bianchi, J., and E. G. Mendoza. 2010. "Overborrowing, Financial Crises and 'Macro-prudential' Taxes." NBER Working Paper No. 16091.

Borgy, V., L. Clerc, and J. P. Renne. 2009. "Asset Price BoomBust Cycles and Credit: What Is the Scope of Macro-Prudential Regulation?" Banque de France Working Paper No. 263.

Borio, C., and M. Drehmann. 2009. "Assessing the Risk of Banking Crises - Revisited." BIS Quarterly Review (March): 29-46.

Borio, C. E. V., and P. W. Lowe. 2002. "Asset Prices, Financial and Monetary Stability: Exploring the Nexus." BIS Working Paper No. 114.

Cardarelli, R., S. Elekdag, and M. A. Kose. 2010. "Capital Inflows: Macroeconomic Implications and Policy Responses." Economic Systems 34 (4): 333-56.

Carlstrom, C. T., and T. S. Fuerst. 1997. "Agency Costs, Net Worth, and Business Fluctuations: A Computable General Equilibrium Analysis." American Economic Review 87 (5): 893-910.

Cespedes, L. F., R. Chang, and A. Velasco. 2004. "Balance Sheets and Exchange Rate Policy." American Economic Review 94 (4): 1183-93.

Christiano, L., M. Eichenbaum, and C. Evans. 2005. "Nominal Rigidities and the Dynamic Effects of a Shock to Monetary Policy." Journal of Political Economy 113 (1): 1-45. 
Cook, D. 2004. "Monetary Policy in Emerging Markets: Can Liability Dollarization Explain Contractionary Devaluations?" Journal of Monetary Economics 51 (6): 1155-81.

Correia, I., J. C. Neves, and S. Rebelo. 1995. "Business Cycles in a Small Open Economy." European Economic Review 39 (6): 1089-1113.

Cúrdia, V. 2007. "Monetary Policy under Sudden Stops." Staff Report No. 278, Federal Reserve Bank of New York.

- 2008. "Optimal Monetary Policy under Sudden Stops." Staff Report No. 323, Federal Reserve Bank of New York.

De Paoli, B. 2009. "Monetary Policy and Welfare in a Small Open Economy." Journal of International Economics 77 (1): 11-22.

Devereux, M. B., P. R. Lane, and J. Xu. 2006. "Exchange Rates and Monetary Policy in Emerging Market Economies." Economic Journal 116 (511): 478-506.

Elekdag, S., and I. Tchakarov. 2007. "Balance Sheets, Exchange Rate Policy, and Welfare." Journal of Economic Dynamics and Control 31 (12): 3986-4015.

Faia, E., and T. Monacelli. 2007. "Optimal Interest Rate Rules, Asset Prices and Credit Frictions." Journal of Economic Dynamics and Control 31 (10): 3228-54.

Farhi, E., and I. Werning. 2012. "Dealing with the Trilemma: Optimal Capital Controls with Fixed Exchange Rates." NBER Working Paper No. 18199.

Gale, D., and M. Hellwig. 1985. "Incentive-Compatible Debt Contract: The One-Period Problem." Review of Economic Studies 52 (4): 647-63.

Galí, J., and T. Monacelli. 2005. "Monetary Policy and Exchange Rate Volatility in a Small Open Economy." Review of Economic Studies 72 (3): 707-34.

Gerdesmeier, D., B. Roffia, and H. E. Reimers. 2009. "Asset Price Misalignments and the Role of Money and Credit." ECB Working Paper No. 1068.

Gertler, M., S. Gilchrist, and F. Natalucci. 2007. "External Constraints on Monetary Policy and the Financial Accelerator." Journal of Money, Credit and Banking 39 (2-3): 295-330.

Gertler, M., and P. Karadi. 2011. "A Model of Unconventional Monetary Policy." Journal of Monetary Economics 58 (1): 17-34. 
Greenwood, J., Z. Hercowitz, and G. Huffman. 1988. "Investment, Capacity Utilization, and the Real Business Cycle." American Economic Review 78 (3): 402-17.

Ingves, S. 2011. "Challenges for the Design and Conduct of Macroprudential Policy." Speech at the Bank of Korea-Bank for International Settlements (BOK-BIS) Conference on Macroprudential Regulation and Policy, Seoul, January 18.

Jeanne, O., and A. Korinek. 2010. "Managing Credit Booms and Busts: A Pigouvian Taxation Approach." NBER Working Paper No. 16377.

Kannan, P., P. Rabanal, and A. Scott. 2009. "Macroeconomic Patterns and Monetary Policy in the Run-Up to Asset Price Busts." IMF Working Paper No. 09/252.

Kiyotaki, N., and J. Moore. 1997. "Credit Cycles." Journal of Political Economy 105 (2): 211-48.

Kohn, D. 2008. "Monetary Policy and Asset Prices Revisited." Speech at the Cato Institute's 26th Annual Monetary Policy Conference, Washington, DC, November 19.

Korinek, A. 2009. "Systemic Risk-Taking: Accelerator Effects, Externalities, and Regulatory Responses." Mimeo, University of Maryland.

Lim, C., F. Columba, A. Costa, P. Kongsamut, A. Otani, M. Saiyid, T. Wezel, and X. Wu. 2011. "Macroprudential Policy: What Instruments and How to Use Them? Lessons from Country Experiences." IMF Working Paper No. 11/238.

Mendoza, E. 1991. "Real Business Cycles in a Small Open Economy." American Economic Review 81 (4): 797-818.

Mishkin, F. S. 2007. "The Transmission Mechanism and the Role of Asset Prices in Monetary Policy." In Monetary Policy Strategy. MIT Press.

N'Diaye, P. 2009. "Countercyclical Macro Prudential Policies in a Supporting Role to Monetary Policy." IMF Working Paper No. 09/257.

Neumeyer, P. A., and F. Perri. 2005. "Business Cycles in Emerging Economies: The Role of Interest Rates." Journal of Monetary Economics 52 (2): 345-80.

Ostry, J. D., A. R. Ghosh, K. Habermeier, L. Laeven, M. Chamon, M. S. Qureshi, and D. B. S. Reinhardt. 2010. "Capital Inflows: The Role of Controls." IMF Staff Position Note No. 10/04. 
Ozkan, G., and D. F. Unsal. 2010. "External Finance, Sudden Stops, and Financial Crisis: What Is Different this Time?" IMF Working Paper No. 10/158.

Rotemberg, J. 1982. "Sticky Prices in the United States." Journal of Political Economy 90 (6): 1187-1211.

Schmitt-Grohe, S., and M. Uribe. 2003. "Closing Small Open Economy Models." Journal of International Economics 61 (1): 16385.

- 2007. "Optimal Simple and Implementable Monetary and Fiscal Rules." Journal of Monetary Economics 54 (6): 1702-25. . 2012. "Prudential Policy for Peggers." NBER Working Paper No. 18031.

Sims, C. 2005. "Second-Order Accurate Solution of Discrete Time Dynamic Equilibrium Models." Mimeo, Princeton University. 